Prepared in cooperation with the Mississippi Department of Environmental Quality, Office of Pollution Control

Characterization of Water Quality in Unmonitored Streams in the Mississippi Alluvial Plain, Northwestern Mississippi, May-June 2006

Scientific Investigations Report 2007-5116 


\section{Characterization of Water Quality in Unmonitored Streams in the Mississippi Alluvial Plain, Northwestern Mississippi, May-June 2006}

By Jeannie R. Bryson, Richard H. Coupe, and Michael A. Manning

Prepared in cooperation with the Mississippi Department of Environmental Quality, Office of Pollution Control

Scientific Investigations Report 2007-5116 


\section{U.S. Department of the Interior DIRK KEMPTHORNE, Secretary}

\section{U.S. Geological Survey Mark D. Myers, Director}

U.S. Geological Survey, Reston, Virginia: 2007

For product and ordering information:

World Wide Web: http://www.usgs.gov/pubprod

Telephone: 1-888-ASK-USGS

For more information on the USGS--the Federal source for science about the Earth, its natural and living resources, natural hazards, and the environment:

World Wide Web: http://www.usgs.gov

Telephone: 1-888-ASK-USGS

Any use of trade, product, or firm names is for descriptive purposes only and does not imply endorsement by the U.S. Government.

Although this report is in the public domain, permission must be secured from the individual copyright owners to reproduce any copyrighted materials contained within this report.

Suggested citation:

Bryson, J.R., Coupe, R.H., and Manning, M.A., 2007, Characterization of water quality in unmonitored streams in the Mississippi Alluvial Plain, northwestern Mississippi, May-June 2006: U.S. Geological Survey Scientific Investigations Report 2007-5116, 20 p. 


\section{Contents}

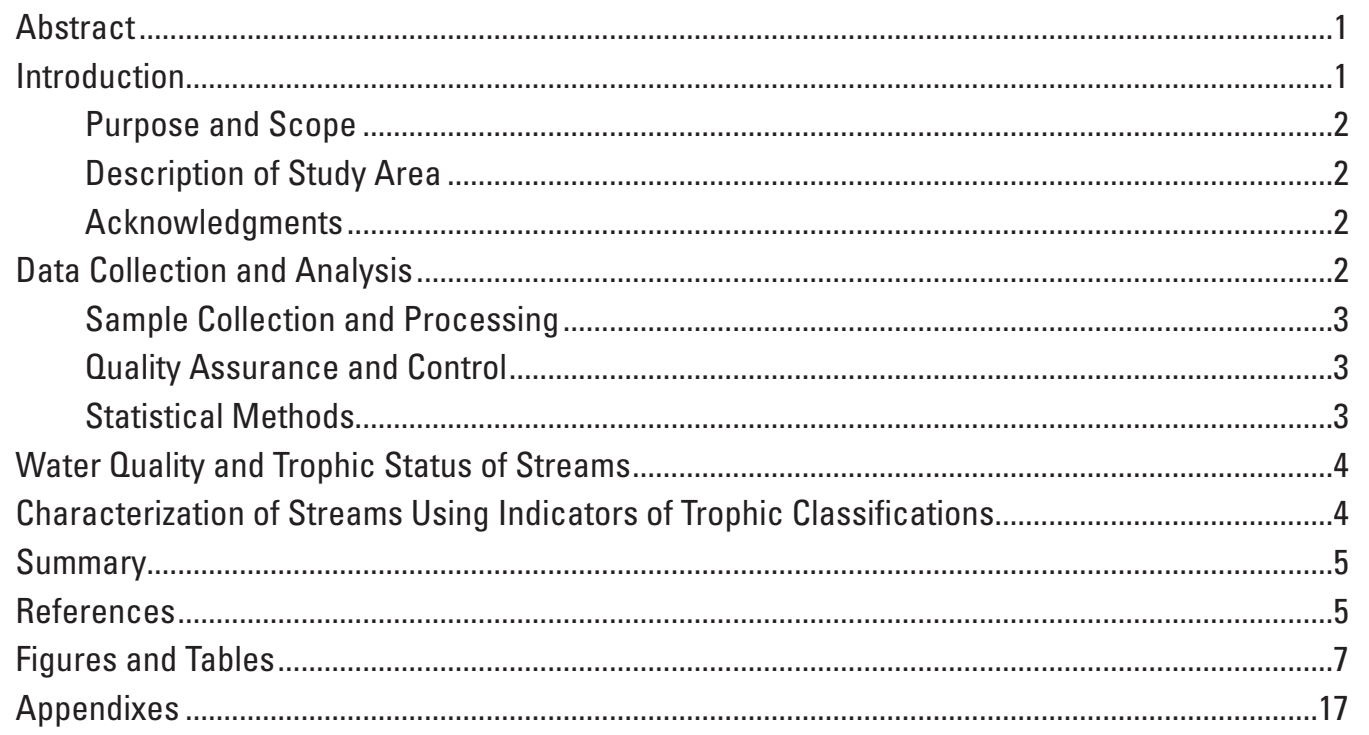




\section{Figures}

1. Map showing location of study area, study sites, and site classification within Nutrient Ecoregion X, subecoregion 73, northwestern Mississippi .............................................

2. Graph showing relation of 8-year (period of record for gage) mean daily streamflow (19972005) with mean daily streamflow and precipitation between August 1, 2005, and August 1, 2006, for streamflow gage on Bogue Phalia near Leland (station 07288650), Mississippi

3. Graphs showing distribution of selected data among trophic groups at 52 stream sites in northwestern Mississippi

4. Graphs showing comparisons and correlation coefficient values ( $r$ ) between chlorophyll a and selected constituents and physical properties in order of decreasing correlation coefficients

5. Graph showing distribution of dissolved oxygen concentrations by sampling times. 13

6. Maps showing relations of (A) total Kjeldhal nitrogen points to stream trophic group, (B) dissolved oxygen points to stream trophic group, (C) turbidity points to stream trophic group, and (D) total stream productivity points to stream trophic group.

\section{Tables}

1. Statistical summary of selected physical properties and constituents in water from all stream sites combined and within each trophic group, northwestern Mississippi, May-June 2006

2. Percentile statistics for indicator physical properties and constituents used to characterize streams in northwestern Mississippi ..............................................................................16

3. Point criteria used to characterize stream productivity in northwestern Mississippi.................16

4. Number of northwestern Mississippi streams in each trophic group for each point criteria ....16 


\begin{tabular}{|c|c|c|}
\hline Multiply & By & To obtain \\
\hline \multicolumn{3}{|c|}{ Length } \\
\hline inch (in.) & 2.54 & centimeter $(\mathrm{cm})$ \\
\hline inch (in.) & 25.4 & millimeter $(\mathrm{mm})$ \\
\hline foot $(\mathrm{ft})$ & 0.3048 & meter $(\mathrm{m})$ \\
\hline micron $(\mu \mathrm{m})$ & 0.00003937 & inch (in.) \\
\hline mile (mi) & 1.609 & kilometer (km) \\
\hline millimeter $(\mathrm{mm})$ & 0.03937 & inch (in.) \\
\hline \multicolumn{3}{|c|}{ Area } \\
\hline square mile $\left(\mathrm{mi}^{2}\right)$ & 2.590 & square kilometer $\left(\mathrm{km}^{2}\right)$ \\
\hline \multicolumn{3}{|c|}{ Volume } \\
\hline gallon (gal) & 3.785 & liter $(\mathrm{L})$ \\
\hline liter $(\mathrm{L})$ & 33.82 & ounce, fluid (oz) \\
\hline milliliter (mL) & 0.0338 & ounce, fluid (oz) \\
\hline \multicolumn{3}{|c|}{ Flow rate } \\
\hline cubic foot per second $\left(\mathrm{ft}^{3} / \mathrm{s}\right)$ & 0.02832 & cubic meter per second $\left(\mathrm{m}^{3} / \mathrm{s}\right)$ \\
\hline foot per second (ft/s) & 0.3048 & meter per second $(\mathrm{m} / \mathrm{s})$ \\
\hline \multicolumn{3}{|c|}{ Pressure } \\
\hline kilopascal (kPa) & 6.895 & $\begin{array}{l}\text { pound-force per square inch } \\
\left(\mathrm{lb} / \mathrm{in}^{2}\right)\end{array}$ \\
\hline
\end{tabular}

Temperature in degrees Celsius $\left({ }^{\circ} \mathrm{C}\right)$ may be converted to degrees Fahrenheit $\left({ }^{\circ} \mathrm{F}\right)$ as follows:

${ }^{\circ} \mathrm{F}=\left(1.8 x^{\circ} \mathrm{C}\right)+32$

Temperature in degrees Fahrenheit $\left({ }^{\circ} \mathrm{F}\right)$ may be converted to degrees Celsius $\left({ }^{\circ} \mathrm{C}\right)$ as follows:

${ }^{\circ} \mathrm{C}=\left({ }^{\circ} \mathrm{F}-32\right) / 1.8$

Vertical coordinate information is referenced to the North American Vertical Datum of 1988 (NAVD 88).

Horizontal coordinate information is referenced to the North American Datum of 1983 (NAD 83).

Specific conductance is given in microsiemens per centimeter at 25 degrees Celsius $(\mu \mathrm{S} / \mathrm{cm}$ at $\left.25^{\circ} \mathrm{C}\right)$.

Concentrations of chemical constituents in water are given either in milligrams per liter (mg/L) or micrograms per liter ( $\mu \mathrm{g} / \mathrm{L})$. 


\title{
Characterization of Water Quality in Unmonitored Streams in the Mississippi Alluvial Plain, Northwestern Mississippi, May-June 2006
}

\author{
By Jeannie R. Bryson, Richard H. Coupe, and Michael A. Manning
}

\section{Abstract}

The Mississippi Department of Environmental Quality is required to develop restoration and remediation plans for water bodies not meeting their designated uses, as stated in the U.S. Environmental Protection Agency's Clean Water Act section 303(d). The majority of streams in northwestern Mississippi are on the 303(d) list of water-quality limited waters. Agricultural effects on streams in northwestern Mississippi have reduced the number of unimpaired streams (reference streams) for water-quality comparisons. As part of an effort to develop an index to assess impairment, the U.S. Geological Survey collected water samples from 52 stream sites on the 303(d) list during May-June 2006, and analyzed the samples for nutrients and chlorophyll.

The data were analyzed by trophic group as determined by total nitrogen concentrations. Seven constituents (nitrite plus nitrate, total Kjeldhal nitrogen, total phosphorus, orthophosphorus, total organic carbon, chlorophyll $a$, and pheophytin $a$ ) and four physical property measurements (specific conductance, $\mathrm{pH}$, turbidity, and dissolved oxygen) were determined to be significantly different $(\mathrm{p}<0.05)$ between trophic groups. Total Kjeldhal nitrogen, turbidity, and dissolved oxygen were used as indicators of stream productivity with which to infer stream health. Streams having high total Kjeldhal nitrogen values and high turbidity values along with low dissolved oxygen concentrations were typically eutrophic (abundant in nutrients), whereas streams having low total Kjeldhal nitrogen values and low turbidity values along with high dissolved oxygen concentrations were typically oligotrophic (deficient in nutrients).

\section{Introduction}

The Mississippi Department of Environmental Quality (MDEQ) is required to develop restoration and remediation plans for water bodies not meeting their designated uses, as stated in the U.S. Environmental Protection Agency's (USEPA) Clean Water Act (CWA) section 303(d). Waterquality data are necessary to develop restoration and remediation plans for streams in northwestern Mississippi. The majority of these streams are unmonitored due to the geomorphol- ogy and inaccessibility of the area (Mississippi Department of Environmental Quality, 2004).

Previous investigations in northwestern Mississippi include a pilot study that collected fish, macroinvertebrate, water-quality, and habitat data to determine which data were most useful as indicators of stream impairment (Rebich and others, 2004). In traditional indicator studies, an index (biotic or abiotic) is developed using reference streams (unimpaired streams), and unmonitored streams are evaluated using the index. Agricultural land use in northwestern Mississippi has reduced the availability of unimpaired streams that can be used to develop an index; therefore, new methods were needed to characterize water quality in northwestern Mississippi. As part of an effort to develop an index to assess impairment, the U.S. Geological Survey (USGS), in cooperation with MDEQ's office of Pollution Control, collected and analyzed water samples from 52 stream sites in an attempt to determine indicators of stream health.

Biological productivity can be used to assess surfacewater quality and the ecological integrity of a stream. Chlorophyll $a$ is considered an indicator of stream productivity because it provides an estimate of algal biomass in the stream (Wetzel, 1983). However, chlorophyll $a$ concentrations can be dependent on other variables and do not always give a complete picture of the stream's productivity level. Nutrients necessary for stream productivity can be harmful in excessive concentrations. Nutrient enrichment can cause algal blooms, which have many detrimental side effects such as bacterial blooms, odor-and-taste problems, and the production of toxins that are harmful to humans and wildlife (U.S. Environmental Protection Agency, 2000). Previous studies have documented the relation between nutrient concentrations and chlorophyll $a$, but few document this relation for streams in the southeastern United States. Carruthers and Wazniak (2005) created a water-quality index for the Maryland Coastal Bays using chlorophyll $a$, total nitrogen, total phosphorus, and dissolved oxygen as indicators of water quality. Their study found that these constituents and physical properties are dependent on the overall water quality of the coastal bays and have implications on the ability of coastal bays to sustain aquatic life. Montgomery and others (1991) determined that nitrogen availability was the limiting factor in phytoplankton production in Charlotte Harbor, Florida. Riskin and others (2003) discussed the relation between total nitrogen and total phosphorus to 
periphyton chlorophyll $a$ and determined that the relation was dependent on canopy cover. Paerl (1997) related the introduction of near-surface nitrogen in coastal environments to increased eutrophication and algal biomass. Nutrient-algal relations are complex and are dependent on other factors such as stream flow, stream water temperature, and light penetration (turbidity) (U.S. Environmental Protection Agency, 2000).

The USEPA has published several documents providing guidance for analyzing nutrient data and developing nutrientalgal relations (U.S. Environmental Protection Agency, 2000, 2001). The Mississippi Alluvial Plain in northwestern Mississippi is part of USEPA Nutrient Ecoregion X and subecoregion 73 (Mississippi Alluvial Plain). The USEPA uses nutrient and chlorophyll data to divide streams in subecoregion 73 into trophic classifications (oligotrophic, mesotrophic, and eutrophic). Trophic refers to the level of available nourishment (nutrients) in a water body. Oligotrophic characterizes water with a deficient supply of plant nutrients and usually an abundant supply of dissolved oxygen. Mesotrophic characterizes water with a moderate level of plant nutrients. Eutrophic characterizes water with a high level of plant nutrients and seasonal deficiencies of oxygen. Total nitrogen was used in this report to divide streams into their respective trophic classification.

\section{Purpose and Scope}

The purpose of this report is to characterize water quality in the Mississippi Alluvial Plain of the Yazoo River Basin in northwestern Mississippi during May and June 2006. Water samples were collected and analyzed for nutrients and chlorophyll $a$, and physical properties were measured at 52 unmonitored stream sites. Streams were divided into trophic classifications using total nitrogen concentrations and USEPA guidance for Nutrient Ecoregion X and subecoregion 73 in an attempt to determine indicators of stream health (U.S. Environmental Protection Agency, 2000, 2001).

\section{Description of Study Area}

More than 50 percent of Mississippi is rural. The largest rural region within Mississippi is the northwestern part of the State, locally referred to as the "Delta" (U.S. Department of Agriculture, 2005). The Delta lies within the Mississippi River Alluvial Plain (MRAP) subecoregion 73 and comprises about one-half of the Yazoo River Basin in northwestern Mississippi (fig. 1). Agriculture is the dominant land use in the Delta. The climate for the MRAP consists of long, hot, humid summers with short, mild winters, which allows for a long growing season of up to 7 months. The soils in the MRAP originate from fertile alluvial/fluvial deposits that are ideal for agricultural use. A clay confining layer is present in some areas of the MRAP, which provides conditions suitable for growing rice as flooded fields help control weed populations. This combination of fertile alluvial soil, long growing season, and plentiful water supply makes the MRAP an extremely productive agricultural area encouraging the use of all available land by agriculture (Mississippi Department of Environmental Quality, 2004).

\section{Acknowledgments}

Data presented in this report were collected as part of a cooperative effort with MDEQ. The authors would like to acknowledge Chris Awwad, David Burt, Scott Jones, Claire Rose, Derek Smith, and Jared Wright of the USGS for their help with the field work necessary for this study.

\section{Data Collection and Analysis}

MDEQ randomly selected 58 unmonitored streams in the Delta for assessment. Six of the 58 streams were dry on the day when sampling was scheduled and, therefore, were not sampled. The unsampled streams were all small ephemeral creeks that are characterized by seasonal, intermittent flow. The remaining 52 streams varied in size from small ephemeral streams to larger perennial (continuous flow) streams, most of which have been channelized. There was little rainfall during the study period as measured at the streamflow gage (fig. 1) on Bogue Phalia near Leland (station 07288650) (fig. 2). Because of the lack of rainfall, velocity in the streams was subsequently low (less than $1.5 \mathrm{ft} / \mathrm{s}$ ) and the water generally was well mixed with respect to stream physical properties.

Streams were grouped based on their trophic classification using USEPA total nitrogen concentration guidelines (U.S. Environmental Protection Agency, 2001). According to USEPA guidance for nutrient Ecoregion $\mathrm{X}$, streams with total nitrogen concentrations less than $0.7 \mathrm{mg} / \mathrm{L}$ are classified as oligotrophic, streams with concentrations greater than or equal to $0.70 \mathrm{mg} / \mathrm{L}$ but less than $1.5 \mathrm{mg} / \mathrm{L}$ are classified as mesotrophic, and streams with concentrations greater than or equal to $1.5 \mathrm{mg} / \mathrm{L}$ are classified as eutrophic. Of the 52 stream sites sampled, 6 were oligotrophic, 20 were mesotrophic, and 26 were eutrophic (fig. 1).

Water-quality data collection was conducted during May and June 2006. All streams sampled are currently listed as impaired on the CWA Section 303(d) list as designated by MDEQ. Samples collected at each stream were analyzed for dissolved solids, chloride, nitrite plus nitrate, ammonia, total Kjeldhal nitrogen (TKN), total phosphorus, orthophosphorus, chlorophyll $a$, pheophytin $a$, and total organic carbon. Physical properties of specific conductance, $\mathrm{pH}$, water temperature, turbidity, dissolved oxygen, and percent oxygen saturation were recorded at each site. Physical properties of chemical oxygen demand, and alkalinity were analyzed at the MDEQ laboratory. Six replicate samples were collected for chloride, nutrients, chlorophyll $a$, and pheophytin $a$. 


\section{Sample Collection and Processing}

Water samples were collected according to established procedures in the USGS National Field Manual for the Collection of Water-Quality Data (Wilde and Radtke, 1998).

The samples were depth and width integrated without using flow-weighted procedures because of the low gradient of the alluvial plain and subsequent low velocities (less than 1 $\mathrm{ft} / \mathrm{s}$ ) either by wading the stream, by sampling from a bridge with a cabled sampler, or by sampling from a boat in remote areas. Water samples were analyzed for chloride and nutrient concentrations by the MDEQ laboratory in Pearl, Mississippi, and water samples were analyzed for chlorophyll $a$ and pheophytin $a$ concentrations by the USGS National Water- Quality Laboratory (NWQL) in Lakewood, Colorado. Samples for all other constituents were analyzed at the MDEQ laboratory. Results of sample analyses for selected constituents are listed in appendix 1.

Sample processing followed guidelines in the MDEQ Quality Assurance Project Plan (QAPP) for Mississippi Delta Fish IBI Study (Mississippi Department of Environmental Quality, 2005), as well as the 2006 Quality Assurance Plan for Water-Quality Activities in the USGS Mississippi Water Science Center (Rebich and others, 2006). All sampling equipment was constructed of either Teflon $®$, glass, or stainless steel, and was cleaned before each sample was collected with a 0.2-percent solution of nonphosphate detergent, rinsed with tap water, and deionized water, allowed to air dry in a dustfree area, and wrapped in either aluminum foil or bagged in plastic bags for protection. At each stream location, three 1-L Teflon ${ }^{\circledR}$ bottles at minimum were filled from transects across the stream and were composited into a Teflon ${ }^{\circledR}$ churn that was rinsed onsite. Aliquots were then split into individual bottles for whole water analysis. Samples that required filtering were filtered onsite using a capsule filter containing a $0.45 \mu \mathrm{m}$ filter and a low-vacuum hand pump.

Samples for chlorophyll $a$, and pheophytin $a$ were processed onsite by filtering a measured volume of water through a 0.47 -mm baked glass-fiber filter held in place by a stainlesssteel filter apparatus and pumped using a low volume (less than $20 \mathrm{kPa}$ ) vacuum. Prior to filtering the water, the sample was thoroughly agitated to suspend the particulates. Various volumes (50-150 mL) were filtered for each chlorophyll $a$ analysis depending on sufficient loading of the filter, which was determined by a green or brown color on each filter. Filters were folded once, enclosed inside a two-piece Petri dish, wrapped in aluminum foil, packed on dry ice, and mailed overnight to NWQL.

Samples for all other constituents were packed on wet ice and delivered to the MDEQ laboratory within 48 hours for analysis. Physical properties were measured using a multiprobe sonde that was calibrated each morning and rechecked at the end of each day. Turbidity was measured using a Hach Turbidimenter 2100P. Samples for turbidity were measured five times, and the median value was recorded. All of the water-quality procedures are described in the Quality-
Assurance Plan for Water-Quality Activities (Rebich and others, 2006).

\section{Quality Assurance and Control}

About 10 percent of all samples submitted to each laboratory were replicates. Replicate samples, listed in appendix 2 , are used to assess variability in each data set. The relative percentage difference (RPD) was calculated for each replicate pair for each constituent using the following equation:

$$
\frac{\left|C_{a}-C_{b}\right|}{\left[\left(C_{a}+C_{b}\right) / 2\right]}
$$

where $\mathrm{C}_{\mathrm{a}}$ equals the concentration of the primary sample, and $\mathrm{C}_{\mathrm{b}}$ equals the concentration of the replicate sample. The average calculated RPD value between replicate samples for all constituents analyzed was 9 percent and ranged from 0 to 66 percent. The average calculated RPD value between replicate samples for constituents discussed later in this report was 9 percent and ranged between 0 and 40 percent. These RPD values indicate that, on average, little variability between replicate samples exists.

The MDEQ laboratory has participated in the Standard Reference Sample project of the USGS-Branch of Quality Assurance since September 2002 (information on web, accessed September 22, 2006, at http://bqs.usgs.gov/srs/). Twice each year (spring and fall), reference samples are sent to the MDEQ laboratory for analysis. Nutrient concentrations in these reference samples are unknown to the participating laboratory. Results from MDEQ analysis are compared to the most probable value of the concentration of that particular constituent. MDEQ has participated in eight such sampling rounds and has successfully measured all constituents.

All USGS personnel in the Mississippi Water Science Center who collect water-quality samples participate each year in the USGS National Field Quality Assurance Program of the USGS Branch of Quality Systems (Stanley and others, 1998). Each participant measures the physical properties of water in reference samples with known concentrations, but which are unknown to the participant. Results determined by the participants are compared to the known values to determine efficiency of both the participant and the equipment used for measuring. USGS Mississippi Water Science Center personnel have participated in the program for several decades, and all have successfully completed these tests.

\section{Statistical Methods}

Streams were classified by trophic group and then statistically summarized within each group. The Kruskal-Wallis statistical test was used to determine any significant differences among median values of constituents for each trophic group (Helsel and Hirsch, 1992). The Kruskal-Wallis test is a nonparametric test and was used in this assessment because water- 
quality data usually do not have a normal distribution. A probability level of 5 percent $(p<0.05)$ was chosen as the significant level between at least two of the three trophic groups. Tukey's multiple comparison test (Helsel and Hirsch, 1992) was then used to determine which trophic groups differed significantly. Boxplots were also created for each constituent and physical property measurement to illustrate differences between each trophic group. Boxplots are useful for comparing ranges between data sets (Helsel and Hirsch, 1992). In this case, they are used to compare the range of values for a single constituent or physical property measurement between each trophic group. Scatter plots were created to determine correlation coefficients for certain constituents within each trophic group. Boxplots were created and the Kruskal-Wallis test was performed using S-Plus software. Tukey's multiple comparison test was perfomed using Statview Statistical Software (SAS Insititute, Inc., 1999).

\section{Water Quality and Trophic Status of Streams}

Summary statistics for selected measured constituents are presented in table 1. Data for each stream are listed in appendix 1. Turbidity values varied over a large range between 7 and 400 nephelometric turbidity units (NTU). Dissolved-oxygen values ranged from well below saturation $(1.6 \mathrm{mg} / \mathrm{L})$ to well above saturation $(13.6 \mathrm{mg} / \mathrm{L})$. TKN values ranged from 0.3 to $5.2 \mathrm{mg} / \mathrm{L}$.

Seven of the constituents and physical property measurements differed significantly $(\mathrm{p}<0.05)$ between at least two of the three trophic groups and include turbidity, dissolved oxygen, TKN, total phosphorus, total organic carbon, chlorophyll $a$, and pheophytin $a$ (fig. 3). Turbidity, dissolved oxygen, and total phosphorus values were statistically different between oligotrophic streams and both mesotrophic and eutrophic streams, although values were not statistically different between mesotrophic and eutrophic streams. TKN values were statistically different between each trophic group. Total organic carbon values were statistically different between mesotrophic and eutrophic streams but not between oligotrophic and either mesotrophic or eutrophic streams. Chlorophyll $a$ and pheophytin $a$ values were statistically different between eutrophic streams and both oligotrophic and mesotrophic streams, although values were not statistically different between oligotrophic and mesotrophic streams.

Regression analysis was performed to determine correlation coefficients (r) for chlorophyll $a$ and the remaining constituents and physical property measurements with statistical significance $(\mathrm{p}<0.05)$. In decreasing order of correlation coefficient, they include pheophytin $a$, TKN, total phosphorus, total organic carbon, dissolved oxygen, $\mathrm{pH}$, turbidity, and specific conductance (fig. 4). Pheophytin $a$ is directly related to chlorophyll $a$ and, therefore, is not considered as an additional dependent variable for productivity. Total phosphorus and total organic carbon are components of photosynthetic production and have a similar relation to chlorophyll $a$ and stream productivity as nitrogen (TKN) (Drever, 1988). Their correlation coefficients are somewhat lower than TKN and indicate that TKN has the stronger relation of the three constituents. Dissolved oxygen and turbidity have low correlation coefficients but are considered somewhat dependent variables of stream productivity on the basis of their statistical significance and statistical differences among at least two trophic groups (fig. 3).

\section{Characterization of Streams Using Indicators of Trophic Classifications}

By using the trophic classification, some interpretation is possible with regard to stream productivity. Oligotrophic streams potentially are the least productive, whereas eutrophic streams potentially are the most productive but possibly the most affected by agriculture. Because the trophic classifications are solely based on total nitrogen (TN) concentrations, it is important to look at other constituents and stream physical properties, as well, to evaluate stream health.

Stream productivity was characterized further on the basis of TKN and potential indicators of stream healthturbidity and dissolved oxygen. TKN was chosen on the basis of its relation to productivity, whereas turbidity and dissolved oxygen were chosen based on their indirect relation to stream health. For example, streams with high turbidity limit the amount of light penetration, thus potentially decreasing productivity; low dissolved oxygen levels can stress or even kill aquatic biota whereas very high dissolved oxygen levels indicate eutrophic conditions and poor water quality. TKN was the only constituent that is statistically significant among the three trophic groups and statistically different between each of the three trophic groups (fig. 3). TKN also has the second highest correlation coefficient with chlorophyll $a$ after pheophytin $a$ (fig. 4), supporting the use of TKN as a relatively strong indicator of stream productivity and water quality. Turbidity is higher for mesotrophic and eutrophic streams than for oligotrophic streams (fig. 3), in part due to increased stream productivity and subsequent plant and algae growth or runoff from adjacent agricultural fields. The median dissolved oxygen value is higher for oligotrophic streams than mesotrophic and eutrophic streams (fig. 3), probably due to higher oxygen consumption in productive streams. Dissolved oxygen typically is not considered a stable measurement of productivity as it varies diurnally in response to sunlight and stream productivity changes. For this study, dissolved oxygen was relatively stable and independent of the measurement time (fig. 5). Measurements made between 1115 and 1300 have the largest range, and the median value for measurements made between 1515 and 1700 is slightly higher than the median values for measurements taken any other time. Measurements 
of dissolved oxygen overlap for each time period and do not indicate a strong dependence on measurement time.

Table 2 shows the $25^{\text {th }}, 50^{\text {th }}$, and $75^{\text {th }}$ percentile values for TKN, turbidity, and dissolved oxygen. These values were used to assign points to each stream, with 1 being the least productive (less than or equal to $25^{\text {th }}$ percentile for TKN and turbidity and greater than or equal to $75^{\text {th }}$ percentile for dissolved oxygen) and 3 being the most productive (greater than $50^{\text {th }}$ percentile for TKN, turbidity, and dissolved oxygen) (table 3). TKN, dissolved oxygen, and turbidity were evaluated independently and then evaluated collectively by summing the points from each (fig. 6, table 4). Points are indicative of the stream's productivity (for example, the higher the value, the more productive the stream). When each indicator is evaluated independently on the basis of point criteria in table 3 , there is not a strong relation between trophic group and points. However, when the indicators are evaluated collectively (noted in total stream productivity points, table 4), there is a definite relation between trophic group and total points. That is, the majority of streams for each trophic group are within the expected point range. High-range streams (7-9 total points) typically are eutrophic streams with comparatively high TKN concentrations, limited light penetration (high turbidity), and low-dissolved oxygen concentrations. Low-range streams (3 total points) typically are oligotrophic streams, which suggest less productivity and, therefore, less aquatic life in the stream. These streams have comparatively low TKN concentrations, good light penetration (low turbidity), and high dissolved-oxygen concentrations. Mid-range streams (4-6 total points) typically are mesotrophic and are more likely to have a balance between all stream-health indicators.

Results from this analysis support the use of trophic classification defined by $\mathrm{TN}$ concentrations to characterize stream productivity in the Mississippi Alluvial Plain. Statistical analysis indicates that stream productivity, as it relates to chlorophyll $a$, is dependent on TKN, turbidity, and dissolved oxygen. A point system that is based on rankings of TKN, turbidity, and dissolved oxygen was used to confirm the trophic classification and to further interpret the data. Caution should be used in interpreting these data as the trophic classification and point system were evaluated on only one sample per stream during one season; however, the results are encouraging as the point system does produce results in agreement with the USEPA guidelines for Nutrient Ecoregion X (U.S. Environmental Protection Agency, 2001).

\section{Summary}

The majority of streams in northwestern Mississippi are on the 303(d) list of water-quality limited waters. Agricultural effects on streams in northwestern Mississippi have reduced the number of unimpaired streams (reference streams) for water-quality comparisons. An effort to evaluate the water quality of these streams has been initiated by the MDEQ in cooperation with the USGS. The USEPA has developed nutrient guidelines for each Nutrient Ecoregion and subecoregion; these guidelines were used to group streams by trophic classification.

Boxplots and regression analysis, as well as other summary statistics, were used to determine indicators of stream productivity. Productivity was described by chlorophyll $a$ and pheophytin $a$ concentrations measured in the streams. Streams with higher concentrations were assumed to have higher productivity. Three indicators of productivity were determined from the statistical analysis--TKN, turbidity, and dissolved oxygen. TKN was the only constituent that differed significantly between each of the three trophic groups. Turbidity was higher for mesotrophic and eutrophic streams than for oligotrophic streams, in part due to increased stream productivity and subsequent plant and algae growth or runoff from adjacent agricultural fields. The median dissolved-oxygen value was higher for oligotrophic streams than for mesotrophic and eutrophic streams, probably due to the higher oxygen consumption in more productive streams.

A point system was developed to characterize streams on the basis of productivity using TKN, turbidity, and dissolved oxygen. Higher ranked streams typically were eutrophic (high productivity), whereas lower ranked streams typically were oligotrophic (low productivity). Stream productivity can be used to infer stream health and determine which streams have a higher risk for algal blooms and fish kills, as well as which streams are more likely to sustain aquatic life.

\section{References}

Carruthers, T., and Wazniak, C., 2005, Development of water quality index for the Maryland coastal bays in Wazniak, C.E. and M.R. Hall [Ed.] Maryland's coastal bays: Ecosystem health assessment 2004: Maryland Department of Natural Resources DNR-12-1202-0009, Tidewater Ecosystem Assessment, Annapolis, MD.

Drever, J.I., 1988, The geochemistry of natural waters: Englewood Cliffs, New Jersey, Prentice Hall, Inc., 437 p.

Helsel, D.R., and Hirsch, R.M., 1992, Statistical methods in water resources: New York, Elsevier Science Publishers, $552 \mathrm{p}$.

Mississippi Department of Environmental Quality, 2004, State of Mississippi Water Quality Assessment 2004 Section 305(b) Report Addendum: Mississippi Department of Environmental Quality, $214 \mathrm{p}$.

Mississippi Department of Environmental Quality, 2005, Quality assurance project plan for Mississippi delta fish IBI study, $52 \mathrm{p}$. 
Montgomery, R.T., McPherson, B.F., and Emmons, E.E., 1991, Effects of nitrogen and phosphorous additions on phytoplankton productivity and chlorophyll $a$ in a subtropical estuary, Charlotte Harbor, Florida: U.S. Geological Survey Water-Resources Investigations Report 91-4077, 33 p.

Omernik, J.M., 1987, Ecoregions of the conterminous United States: Annuals of the Association of American Geographers, v. 77, p. 118-125.

Paerl, H.W., 1997, Coastal eutrophication and harmful algal blooms--importance of atmospheric deposition and groundwater as "new" nitrogen and other nutrient sources: Limnology and Oceanography, p. 1154-1165

Rebich, R.A., Manning, M.A., and Morris, F., 2006, Quality assurance plan for water-quality activities in the Mississippi Distict: Unpublished material on file with U.S. Geological Survey in Jackson, Mississippi.

Rebich, R.A., Welch, H.L., and Coupe, R.H., 2004, Evaluation of water-quality and habitat assessment data to determine ranges in stream conditions in the Mississippi River Alluvial Plain of northwestern Mississippi and eastern Arkansas: U.S. Geological Survey Water-Resources Investigations Report 03-4251, 47p.

Riskin, M.L., Deacon, J.R., Liebman, M.L., and Robinson, K.W., 2003, Nutrient and chlorophyll relations in selected streams of the New England Coastal Basins in Massachusetts and New Hampshire, June-September 2001: U.S. Geological Survey Water-Resources Investigations Report 03-4191, 16 p.

SAS Institute, Inc., 1999, Statview reference guide: Cary, North Carolina, version 8.0, unnumbered pages.

S-PLUS Professional Developer, Insightful Corp., 2005, version 7.0.

Stanley, D.L., Boozer, T.M., and Schroder, L.J., 1998, Summary of the U.S. Geological Survey National Field Quality Assurance Program from 1979 through 1997: U.S. Geological Survey Open-File Report 98-392, 11 p.

U.S. Department of Agriculture, 2005, The economics of food, farming, natural resources, and rural America--Economic Research Services, State Fact Sheets: Mississippi, information available on the Web, accessed 1/15/2007, http://www. ers.usda.gov/StateFacts/MS.htm.

U.S. Environmental Protection Agency, 2000, Nutrient criteria technical guidance manual Rivers and streams: Office of Water, EPA 822-B-00-002, variously paged.

U.S. Environmental Protection Agency, 2001, Ambient water quality criteria recommendations_-information supporting the development of State and tribal nutrient criteria-rivers and streams in Nutrient Ecoregion X: Office of Water, EPA 822-B-01-016, variously paged.
Wetzel, R.G., 1983, Limnology: Philadelphia, Pennsylvania, Saunders College Publishing, p. 291-295.

Wilde, F.D., and Radtke, D.B., 1998, National field manual for the collection of water-quality data: U.S. Geological Survey Techniques of Water-Resources Investigations, book 9, variously paginated. 


\section{FIGURES AND TABLES}




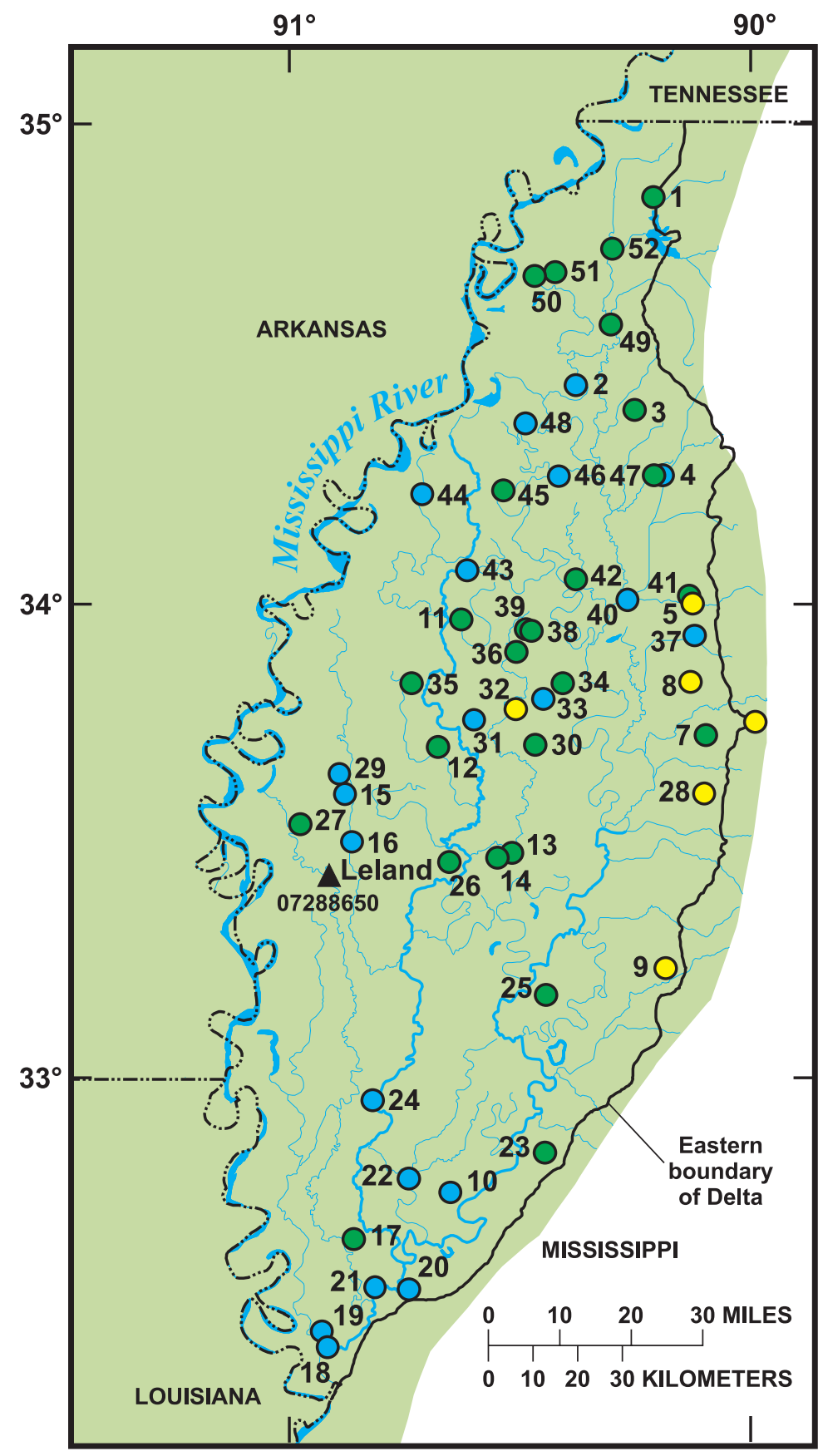

\section{EXPLANATION \\ Nutrient Ecoregion X}

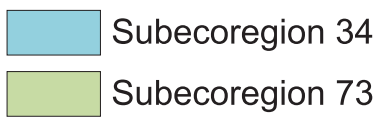

Study sites and tropic classifications

O Oligotrophic water Total nitrogen concentration less than 0.70 milligrams per liter

O Mesotrophic water -

Total nitrogen concentration

0.70 to 1.5 milligrams per liter

Eutrophic water -

Total nitrogen concentration greater than 1.5 milligrams per liter

41 Site number used in appendixes

$\Delta$ U.S. Geological Survey precipitation and 07288650 streamflow-gaging station and number Data shown in figure 2.

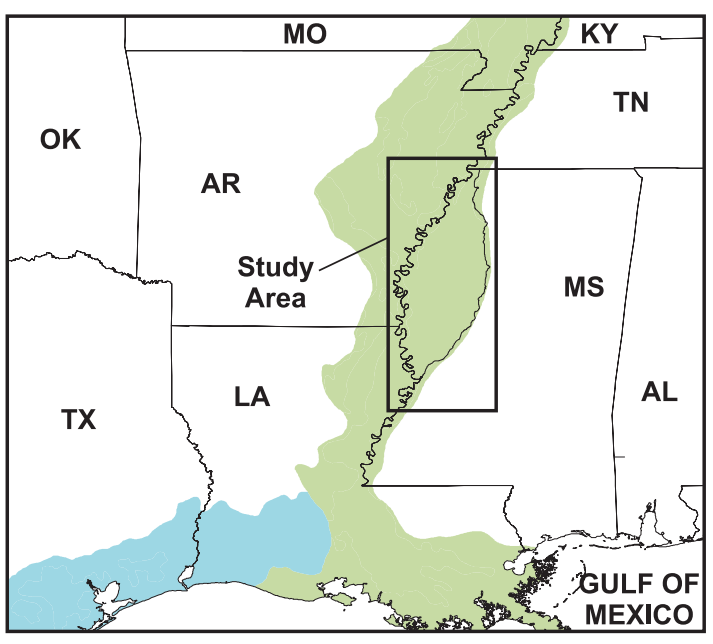

Figure 1. Location of study area, study sites, and site classification within Nutrient Ecoregion $\mathrm{X}$, subecoregion 73, northwestern Mississippi. Ecoregions from Omernik (1987) 


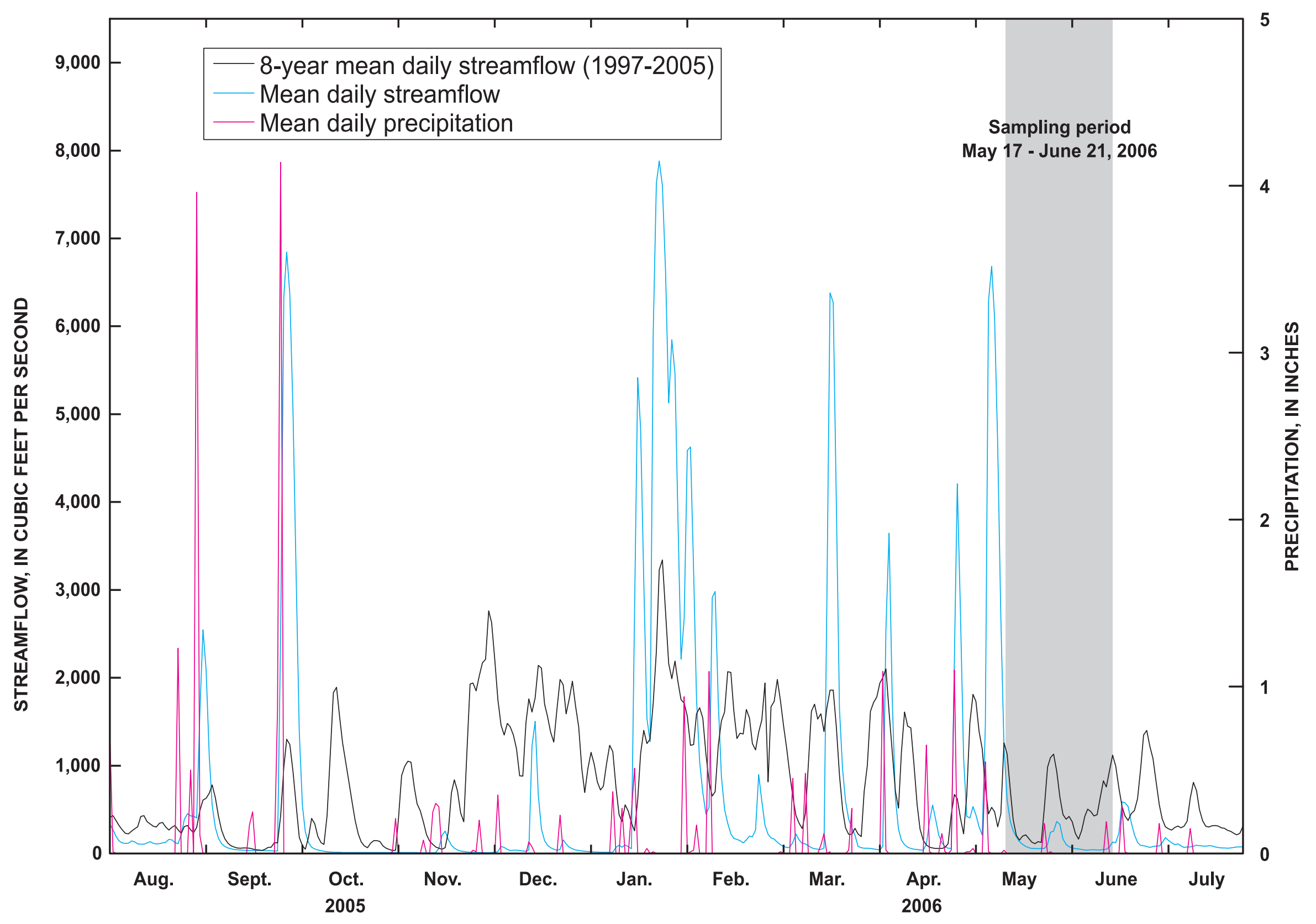

Figure 2. Relation of 8-year (period of record for gage) mean daily streamflow (1997-2005) with mean daily streamflow and precipitation between August 1, 2005, and August 1, 2006, for streamflow gage on Bogue Phalia near Leland, Mississippi (station 07288650). Location of gage shown in figure 1. 

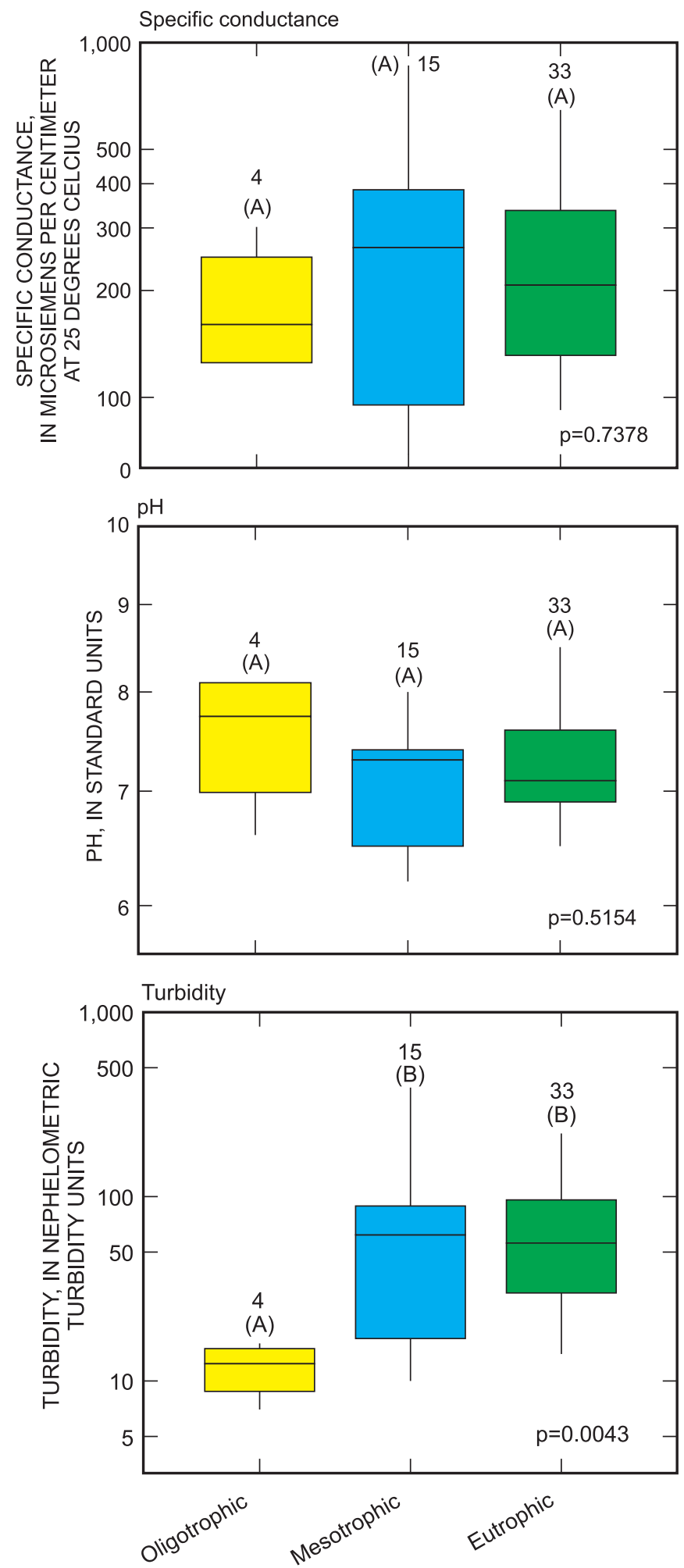
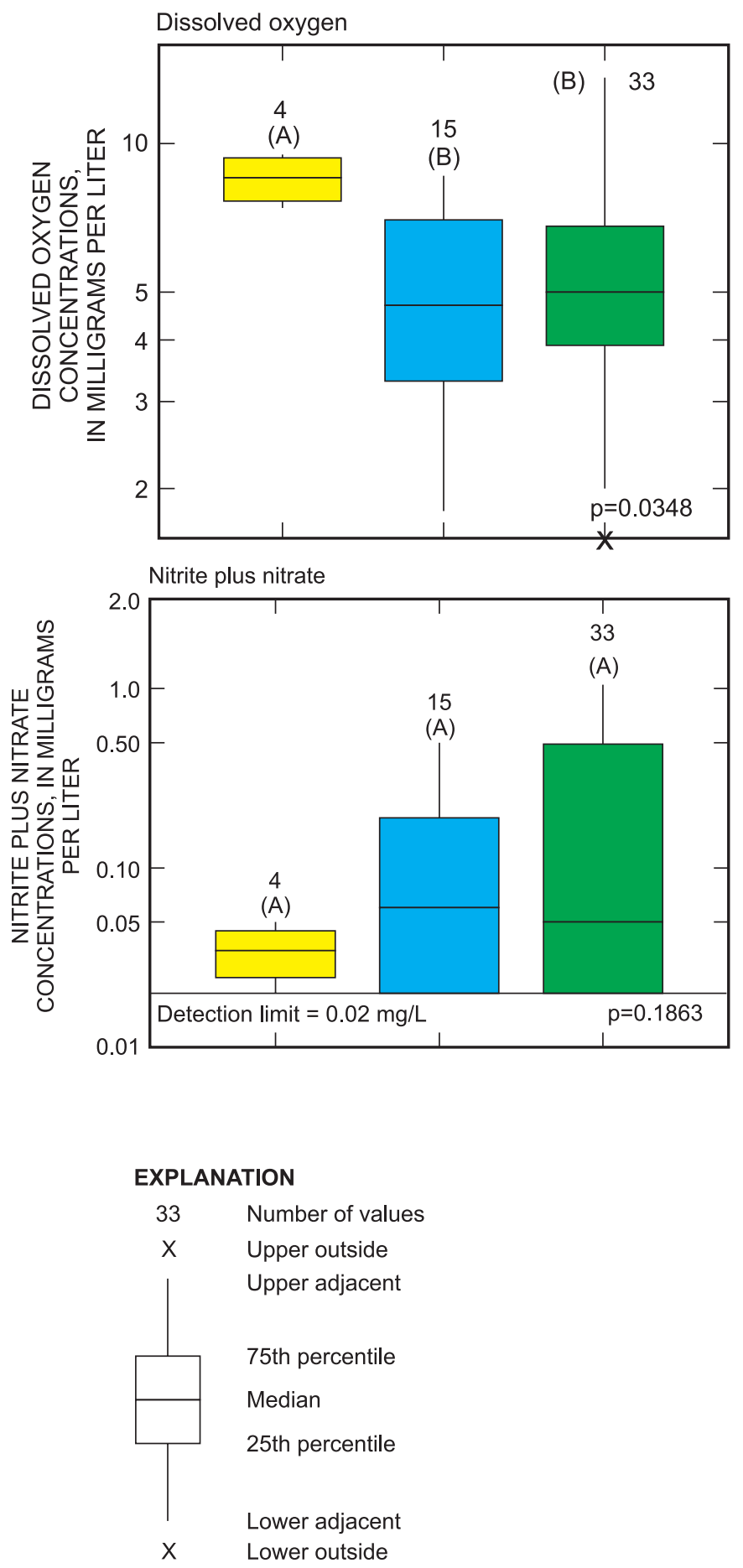

Figure 3. Distribution of selected data among trophic groups at 52 stream sites in northwestern Mississippi. Results of KruskalWallis statistical test for each constituent are presented as $p$ in the bottom right corner of each boxplot. Results of Tukey's multiple comparison test are presented as letters above each trophic group within each boxplot. Concentration ranges with different letters differ statistically from one another (Helsel and Hirsch, 1992). 
Total Kjeldhal nitrogen
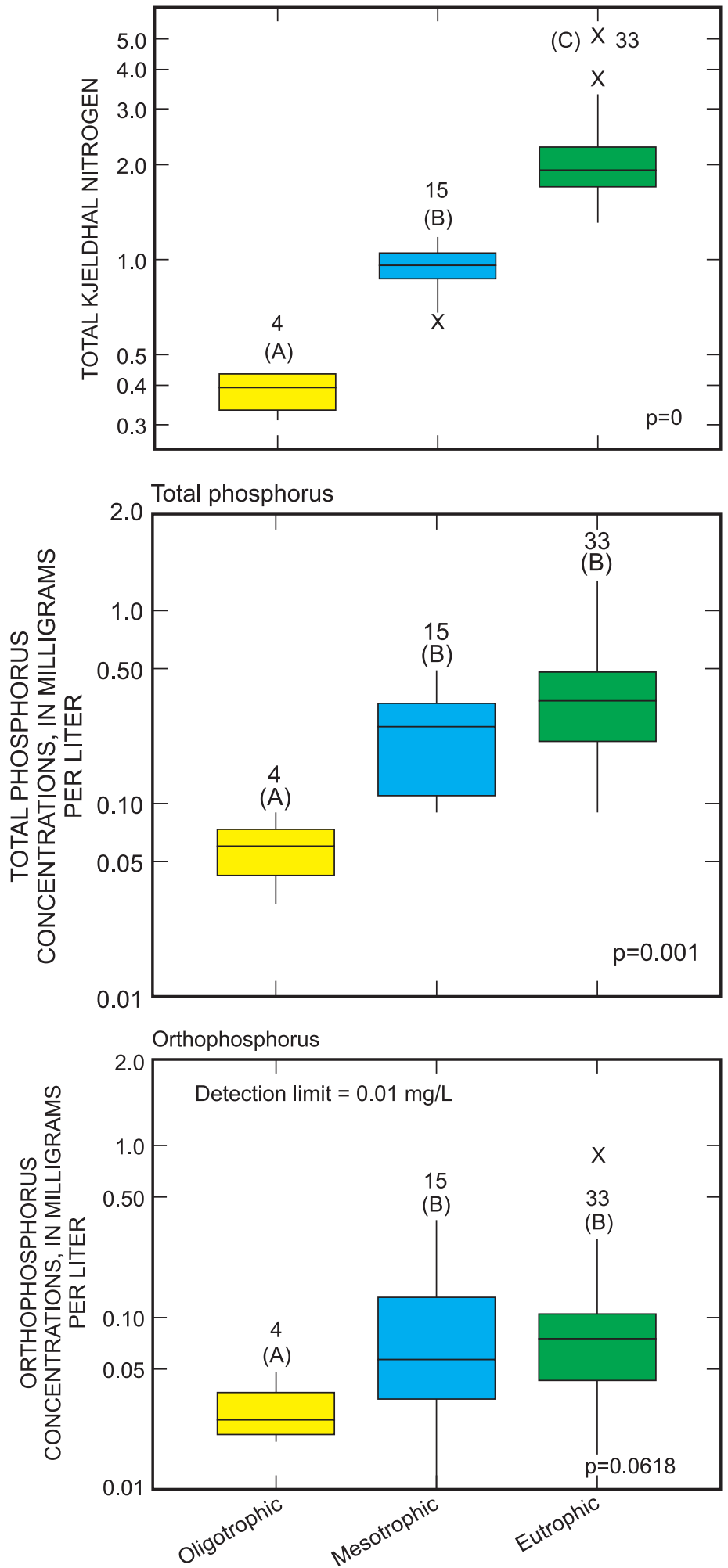
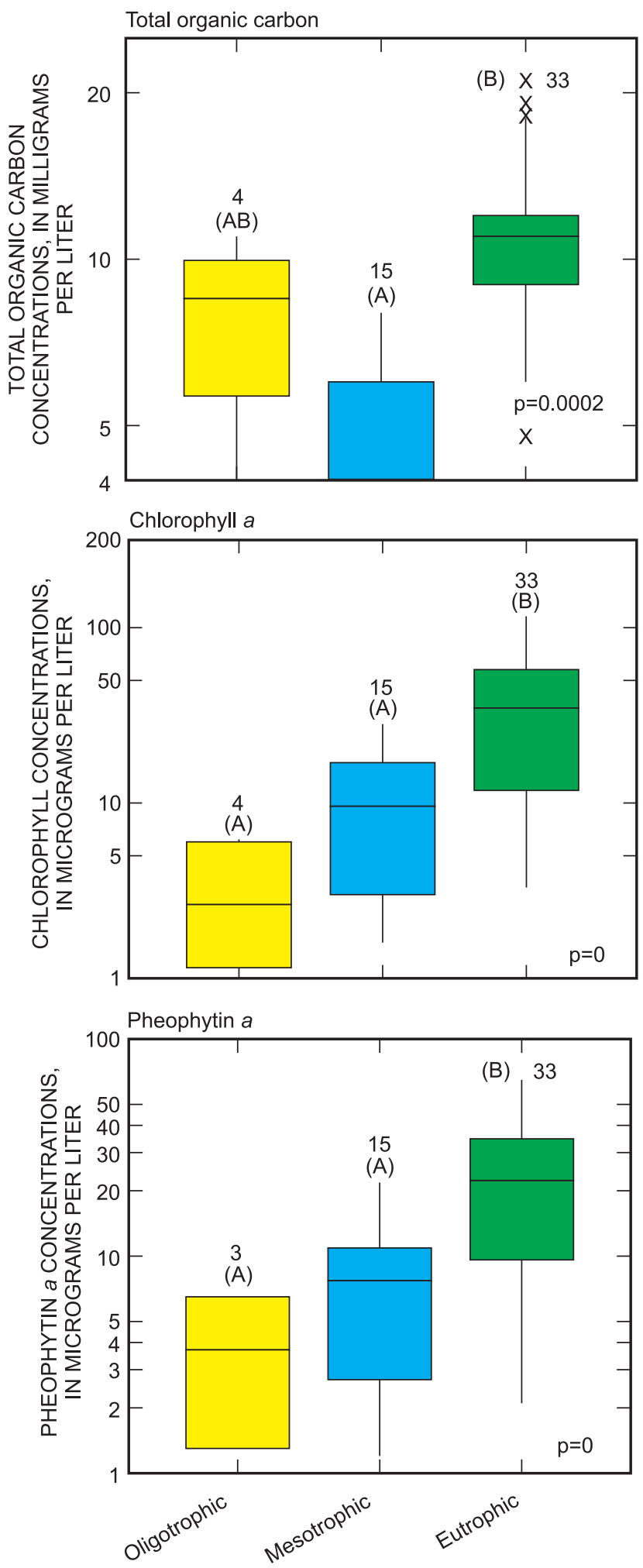

Figure 3. Distribution of selected data among trophic groups at 52 stream sites in northwestern Mississippi. Results of KruskalWallis statistical test for each constituent are presented as $p$ in the bottom right corner of each boxplot. Results of Tukey's multiple comparison test are presented as letters above each trophic group within each boxplot. Concentration ranges with different letters differ statistically from one another (Helsel and Hirsch, 1992). -- Continued 

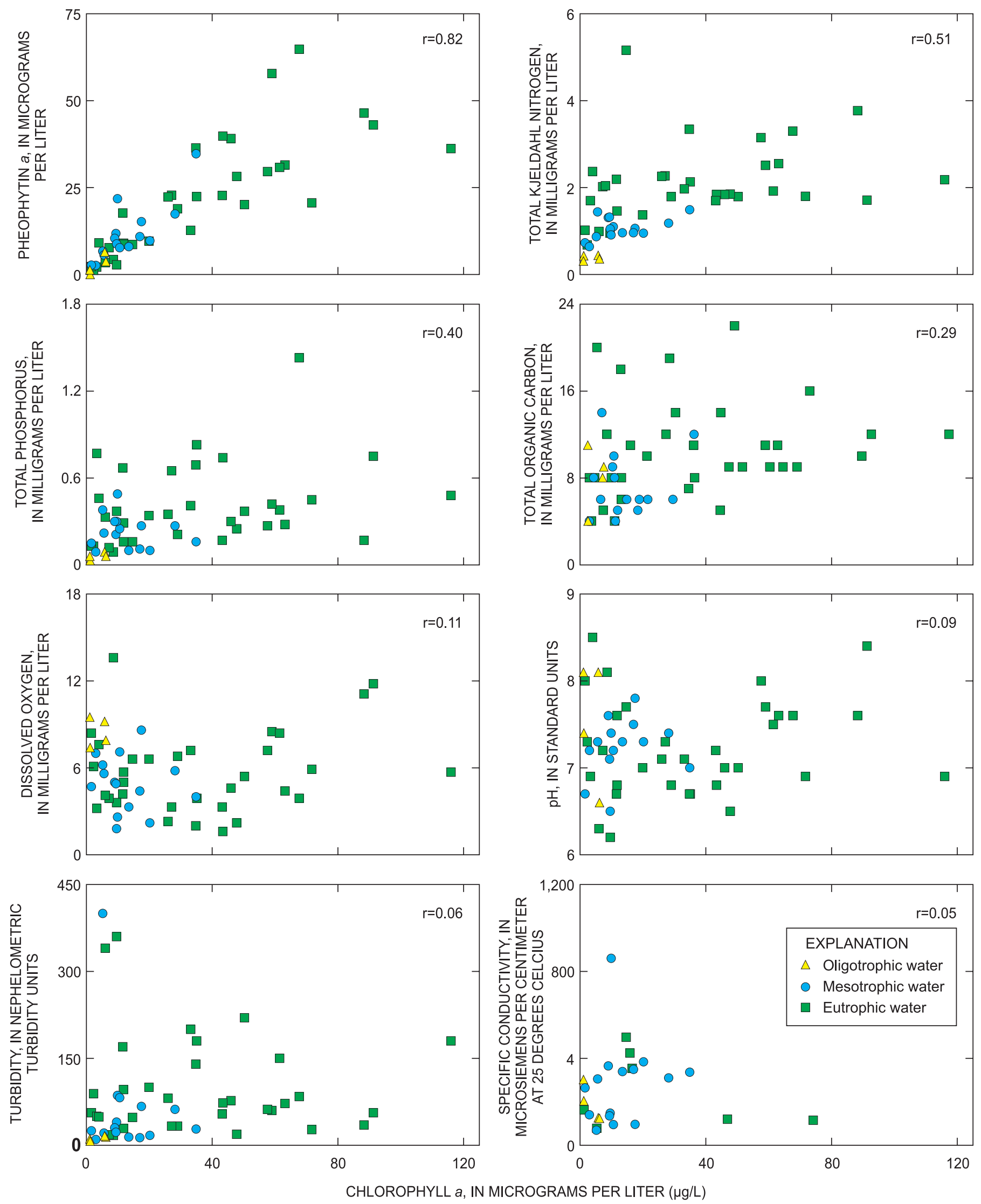

Figure 4. Comparisons and correlation coefficient values between chlorophyll a and selected constituents and physical properties in order of decreasing correlation coefficients. 


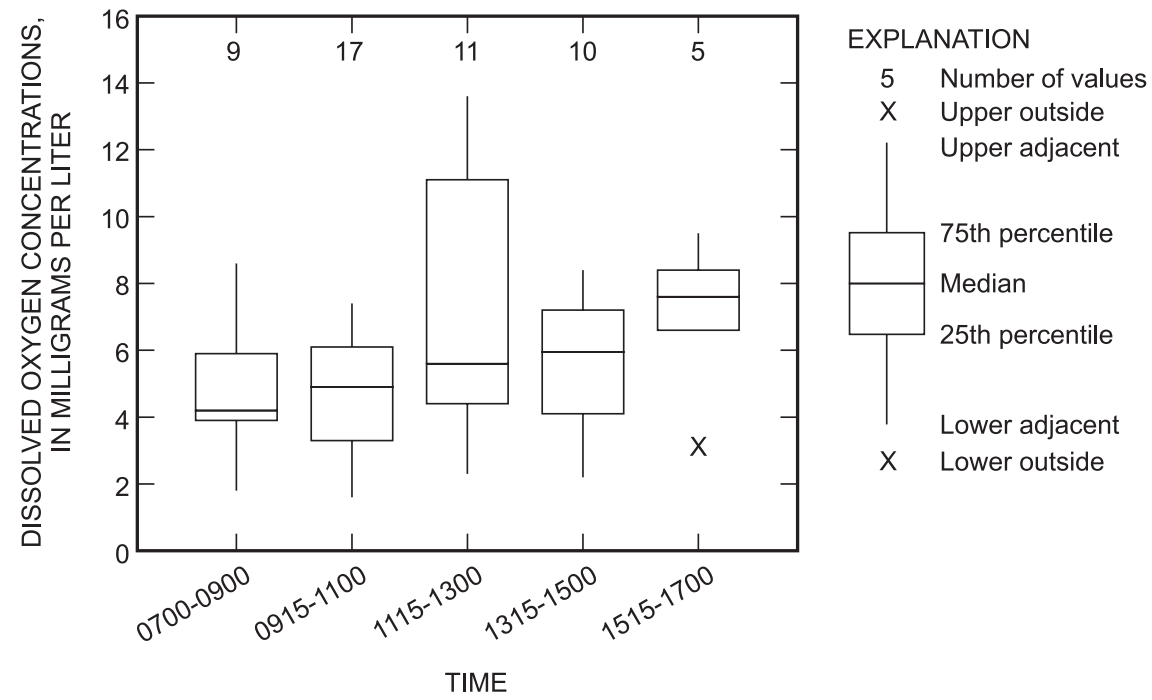

Figure 5. Distribution of dissolved oxygen concentrations by sampling times. 
(A) Total Kjeldhal nitrogen

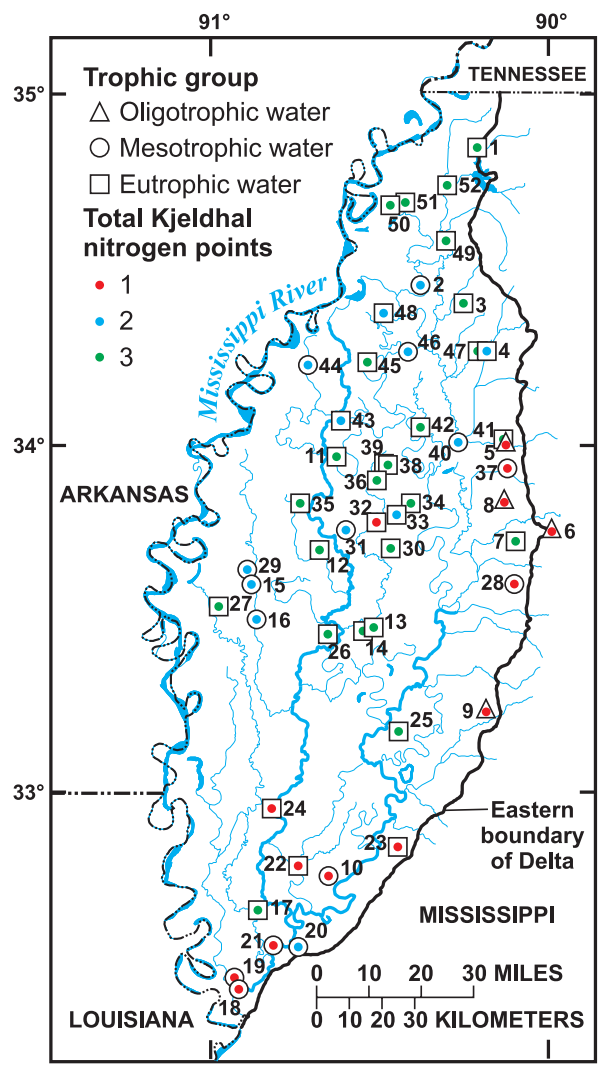

(C) Turbidity

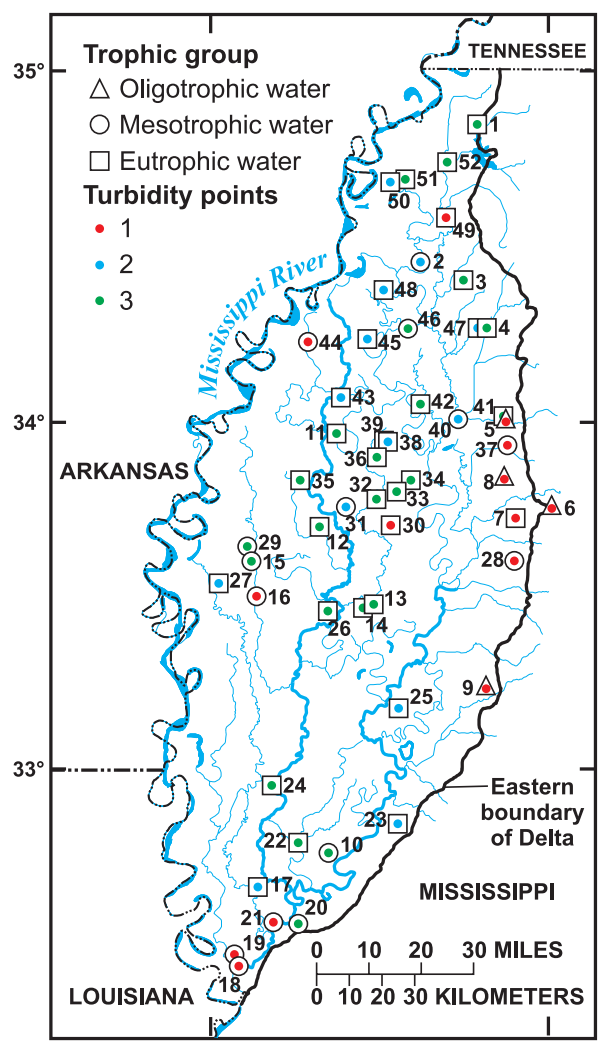

(B) Dissolved oxygen

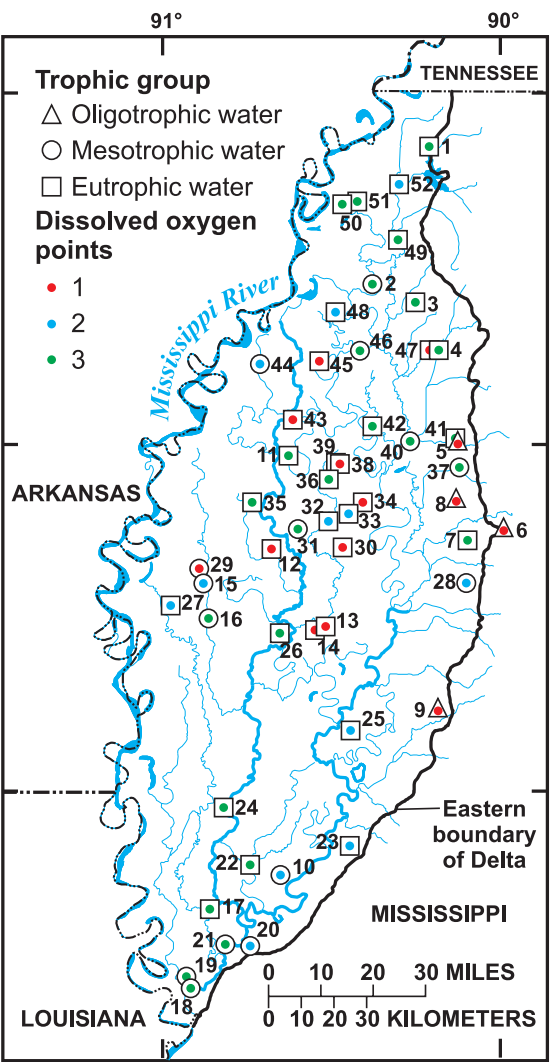

(D) Total stream productivity

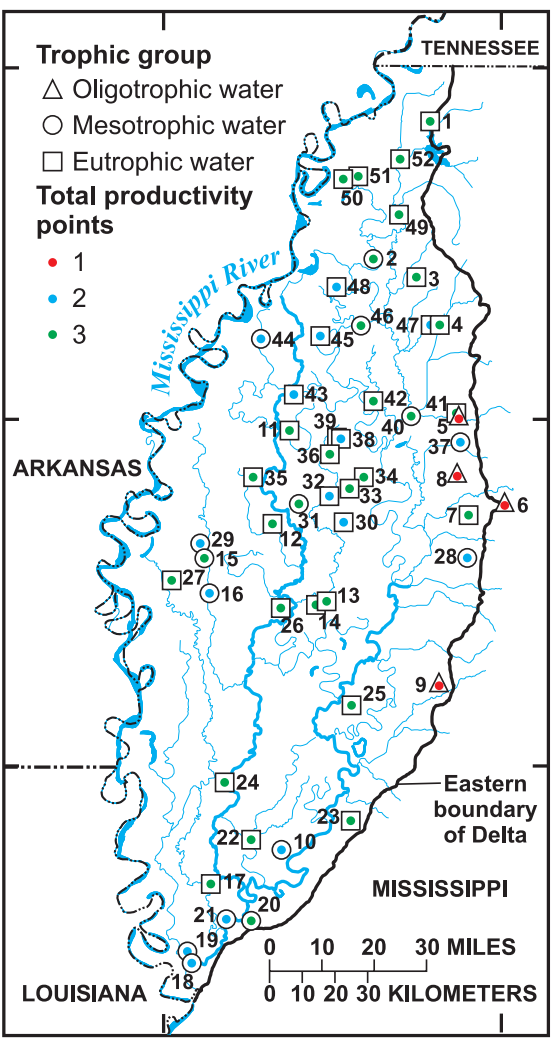

Figure 6. Relations of (A) total Kjeldhal nitrogen points to stream trophic group, (B) dissolved oxygen points to stream trophic group, (C) turbidity points to stream trophic group, and (D) total stream productivity points (total Kjeldhal nitrogen plus dissolved oxygen plus turbidity) to stream trophic group. 
Table 1. Statistical summary of selected physical properties and constituents in water from all stream sites combined and within each trophic group, northwestern Mississippi, May - June 2006

[Min, minimum; Max, maximum; NTU, nephelometric turbidity units; mg/L, milligrams per liter; $\mu \mathrm{S} / \mathrm{cm}$, microsiemens per centimeter; $\mu \mathrm{g} / \mathrm{L}$, micrograms per liter; <, less than; --, not determined]

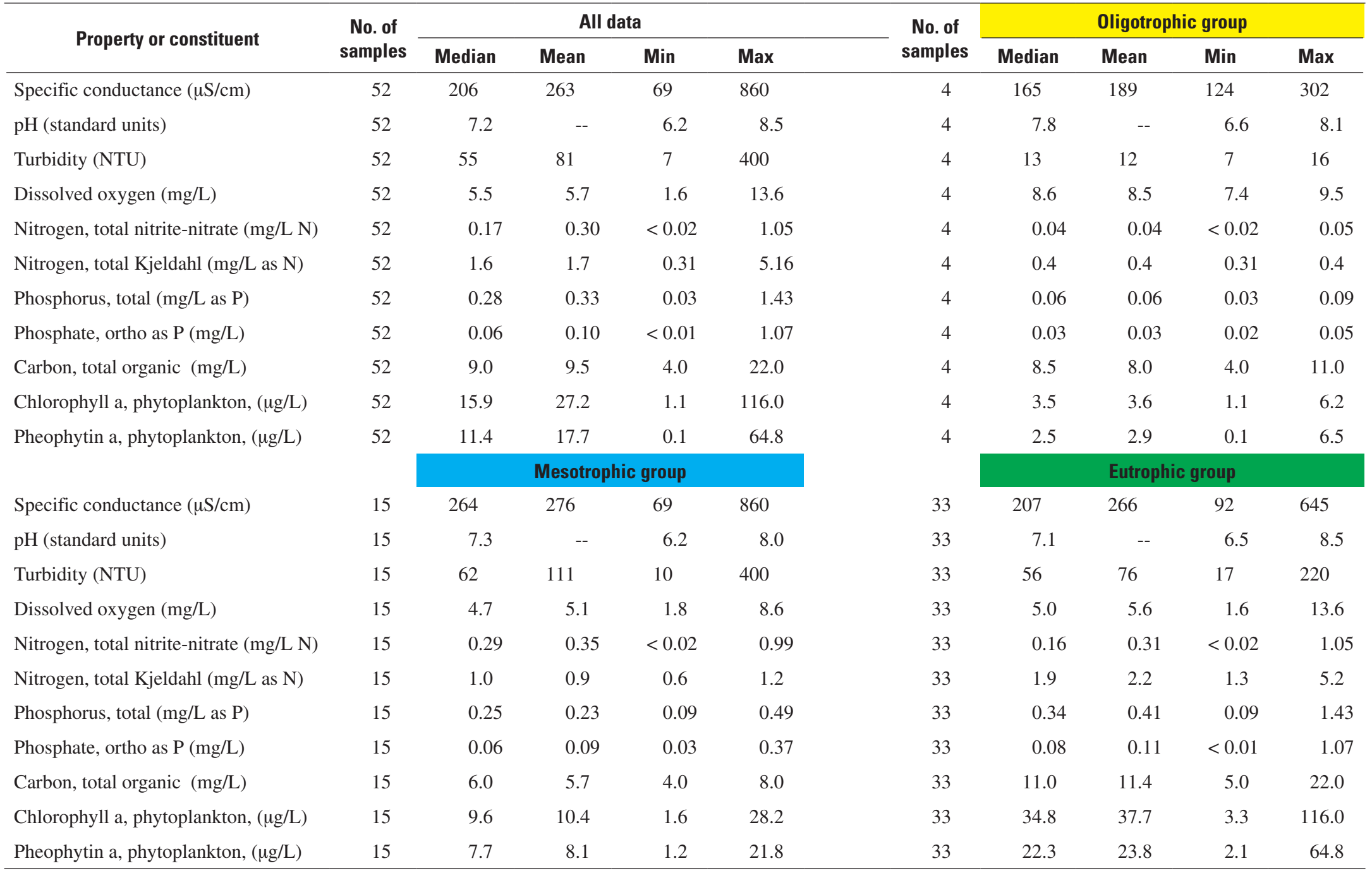


Table 2. Percentile statistics for indicator constituents or physical properties used to characterize streams in northwestern Mississippi

[TKN, total Kjeldahl nitrogen; mg/L, milligrams per liter; NTU, nephelometric turbidity units]

\begin{tabular}{lccc}
\hline \multirow{2}{*}{$\begin{array}{c}\text { Constituent or physical } \\
\text { property (unit of } \\
\text { measurement) }\end{array}$} & \multicolumn{3}{c}{ Percentile concentration } \\
\cline { 2 - 4 } & $\begin{array}{c}\text { 25th } \\
\text { percentile }\end{array}$ & $\begin{array}{c}\text { 50th } \\
\text { percentile }\end{array}$ & $\begin{array}{c}\text { 75th } \\
\text { percentile }\end{array}$ \\
\hline TKN (mg/L) & 0.99 & 1.7 & 2.0 \\
Turbidity (NTU) & 24 & 55 & 87 \\
Dissolved oxygen (mg/L) & 3.9 & 5.5 & 7.2 \\
\hline
\end{tabular}

Table 3. Point criteria used to characterize stream productivity in northwestern Mississippi

[TKN, total Kjeldahl nitrogen; mg/L, milligrams per liter; NTU, nephelometric turbidity units; $\geq$, less than or equal to; $>$, greater than; $<$, less than]

\begin{tabular}{|c|c|c|c|}
\hline \multirow{2}{*}{$\begin{array}{l}\text { Constituent or } \\
\text { physical } \\
\text { property (unit of } \\
\text { measurement) }\end{array}$} & \multicolumn{3}{|c|}{ Point criteria } \\
\hline & 1 & 2 & 3 \\
\hline TKN (mg/L) & $\begin{array}{c}\geq 25 \text { th } \\
\text { percentile }\end{array}$ & $\begin{array}{l}\geq 50 \text { th percentile } \\
>25 \text { th percentile }\end{array}$ & $\begin{array}{c}>50 \text { th } \\
\text { percentile }\end{array}$ \\
\hline Turbidity (NTU) & $\begin{array}{c}\geq 25 \text { th } \\
\text { percentile }\end{array}$ & $\begin{array}{l}\geq 50 \text { th percentile } \\
>25 \text { th percentile }\end{array}$ & $\begin{array}{c}>50 \text { th } \\
\text { percentile }\end{array}$ \\
\hline $\begin{array}{c}\text { Dissolved } \\
\text { oxygen }(\mathrm{mg} / \mathrm{L})\end{array}$ & $\begin{array}{l}\geq 75 \text { th } \\
\text { percentile }\end{array}$ & $\begin{array}{l}\geq 75 \text { th percentile } \\
>50 \text { th percentile }\end{array}$ & $\begin{array}{c}<50 \text { th } \\
\text { percentile }\end{array}$ \\
\hline
\end{tabular}

Table 4. Number of northwestern Mississippi streams in each trophic group for each point criteria.

[Highlighted cells represent the point criteria with the largest number of streams for each trophic group.]

\begin{tabular}{|c|c|c|c|c|c|c|c|}
\hline \multicolumn{4}{|c|}{ Number of streams meeting total Kjeldahl nitrogen criteria } & \multicolumn{4}{|c|}{ Number of streams meeting turbidity criteria } \\
\hline \multirow[b]{2}{*}{ Trophic group } & \multicolumn{3}{|c|}{ Points } & \multirow[b]{2}{*}{ Trophic group } & \multicolumn{3}{|c|}{ Points } \\
\hline & 1 & 2 & 3 & & 1 & 2 & 3 \\
\hline Mesotrophic & 7 & 8 & 0 & Mesotrophic & 7 & 3 & 5 \\
\hline Eutrophic & 3 & 4 & 26 & Eutrophic & 3 & 11 & 19 \\
\hline & \multicolumn{3}{|c|}{ Points } & & \multicolumn{3}{|c|}{ Points } \\
\hline Trophic group & 1 & 2 & 3 & Trophic group & $0-3$ & 4-6 & $7-9$ \\
\hline Oligotrophic & 4 & 0 & 0 & Oligotrophic & 4 & 0 & 0 \\
\hline Mesotrophic & 1 & 5 & 9 & Mesotrophic & 0 & 9 & 6 \\
\hline
\end{tabular}


[TKN, total Kjeldahl nitrogen; $\mu \mathrm{S} / \mathrm{cm}$, microsiemens per centimeter at 25 degrees Celsius; NTU, nephelometric turbidity units; mg/L, milligrams per liter; CaCO3, calcium carbonate; <, less than]

\begin{tabular}{|c|c|c|c|c|c|c|c|c|c|c|c|c|c|c|c|c|c|c|c|}
\hline $\begin{array}{l}\text { Site } \\
\text { num- } \\
\text { ber } \\
\text { (fig. } \\
\text { 1) }\end{array}$ & Station number & $\begin{array}{c}\text { Sample } \\
\text { date } \\
\text { (month/ } \\
\text { day/ } \\
\text { year) }\end{array}$ & $\begin{array}{c}\text { Sam- } \\
\text { ple } \\
\text { start } \\
\text { time } \\
\text { (24- } \\
\text { hour) }\end{array}$ & $\begin{array}{c}\text { Spe- } \\
\text { cific } \\
\text { con- } \\
\text { duc- } \\
\text { tance, } \\
\text { field } \\
(\mu \mathrm{S} / \\
\mathrm{cm})\end{array}$ & $\begin{array}{c}\mathrm{pH}, \\
\text { field } \\
\text { (stan- } \\
\text { dard } \\
\text { units) }\end{array}$ & $\begin{array}{c}\text { Water } \\
\text { tem- } \\
\text { pera- } \\
\text { ture } \\
\text { (de- } \\
\text { grees } \\
\text { Cel- } \\
\text { sius) }\end{array}$ & $\begin{array}{l}\text { Tubidity } \\
\text { (NTU) }\end{array}$ & $\begin{array}{c}\text { Dissolved } \\
\text { oxygen } \\
\text { (mg/L) }\end{array}$ & $\begin{array}{l}\text { Chemi- } \\
\text { cal } \\
\text { oxygen } \\
\text { demand }\end{array}$ & $\begin{array}{l}\text { Alkalinity } \\
\text { as CaC03 }\end{array}$ & $\begin{array}{l}\text { Chloride } \\
\text { (mg/L as } \\
\text { Cl) }\end{array}$ & $\begin{array}{l}\text { Nitrite plus } \\
\text { nitrate } \\
\text { (mg/ L } \\
\text { as N) }\end{array}$ & $\begin{array}{c}\text { Amonia } \\
\text { (mg/L as } \\
\mathrm{N})\end{array}$ & $\begin{array}{c}\text { Nitrogen, } \\
\text { total Kjel- } \\
\text { dahl (mg/L } \\
\text { as } \mathrm{N})\end{array}$ & $\begin{array}{c}\text { Total } \\
\text { phosph- } \\
\text { orus (mg/L } \\
\text { as } \mathrm{P})\end{array}$ & $\begin{array}{l}\text { Dissolved } \\
\text { ortho- } \\
\text { phospho- } \\
\text { rus (mg/L } \\
\text { as P) }\end{array}$ & $\begin{array}{l}\text { Car- } \\
\text { bon, } \\
\text { total } \\
\text { or- } \\
\text { gan- } \\
\text { ic } \\
(\mathrm{mg} / \\
\text { L) }\end{array}$ & $\begin{array}{c}\text { Chlo- } \\
\text { ro- } \\
\text { phyll- } \\
\text { a } \\
(\mu \mathrm{g} / \mathrm{L})\end{array}$ & $\begin{array}{c}\text { Pheo- } \\
\text { phytin } \\
\text { a, } \\
\text { phyto- } \\
\text { plank- } \\
\text { ton } \\
\text { (mg/L\}) }\end{array}$ \\
\hline 1 & 07279144 & $5 / 30 / 2006$ & 855 & 229 & 6.7 & 22.9 & 170 & 4.2 & 64 & 107.0 & 1.1 & $<0.02$ & 0.20 & 2.19 & 0.67 & 0.03 & 18 & 11.6 & 17.7 \\
\hline 2 & 07279836 & $5 / 31 / 2006$ & 830 & 148 & 6.5 & 24.9 & 40 & 1.8 & 26 & 67.3 & 2.4 & 0.04 & $<0.10$ & 1.05 & 0.3 & 0.12 & 8 & 9.6 & 8.8 \\
\hline 3 & 07279937 & $5 / 31 / 2006$ & 950 & 123 & 6.7 & 27.4 & 140 & 2.0 & 46 & 61.4 & $<1$ & $<0.02$ & 0.15 & 3.34 & 0.69 & 0.03 & 11 & 34.8 & 36.4 \\
\hline 4 & 07279970 & $5 / 31 / 2006$ & 1120 & 147 & 6.8 & 26.0 & 96 & 5.0 & 29 & 52.4 & 4.8 & 0.41 & 0.32 & 1.46 & 0.29 & 0.04 & 8 & 11.8 & 9.0 \\
\hline 5 & 07280555 & 6/13/2006 & 1245 & 126 & 8.1 & 28.6 & 16 & 9.2 & 10 & 50.5 & 7.2 & 0.05 & $<0.10$ & 0.44 & 0.09 & 0.03 & 8 & 5.8 & 6.5 \\
\hline 6 & 07285740 & $6 / 12 / 2006$ & 1335 & 124 & 6.6 & 29.4 & 14 & 7.9 & $<10$ & 50.9 & 6.6 & 0.04 & $<0.10$ & 0.36 & 0.06 & 0.02 & 9 & 6.2 & 3.7 \\
\hline 7 & 07285755 & $6 / 12 / 2006$ & 1450 & 92 & 6.5 & 30.2 & 19 & 2.2 & 28 & 48.0 & 3.9 & $<0.02$ & $<0.10$ & 1.85 & 0.25 & 0.02 & 22 & 47.8 & 28.2 \\
\hline 8 & 07286006 & 6/12/2006 & 1630 & 302 & 8.1 & 36.0 & 11 & 9.5 & 79 & 141.0 & 6.4 & $<0.02$ & $<0.10$ & 0.31 & 0.06 & 0.05 & 11 & 1.1 & 1.3 \\
\hline 9 & 07287310 & 6/12/2006 & 950 & 204 & 7.4 & 28.7 & 7 & 7.4 & $<10$ & 93.3 & 4.2 & 0.03 & $<0.10$ & 0.43 & 0.03 & 0.02 & 4 & 1.2 & 0.1 \\
\hline 10 & 07287610 & $5 / 18 / 2006$ & 1450 & 69 & 6.3 & 22.1 & 400 & 6.2 & 29 & 23.0 & 2.4 & 0.50 & 0.21 & 0.87 & 0.38 & 0.05 & 6 & 5.2 & 6.7 \\
\hline 11 & 07288185 & $5 / 24 / 2006$ & 915 & 645 & 7.6 & 26.6 & 72 & 4.4 & 12 & 169.0 & 62.6 & $<0.02$ & 0.33 & 2.55 & 0.28 & 0.03 & 9 & 63.2 & 31.5 \\
\hline 12 & 07288365 & 6/14/2006 & 830 & 635 & 7.7 & 26.9 & 60 & 8.5 & 35 & 242.0 & 46.2 & 0.04 & $<0.10$ & 2.51 & 0.42 & 0.11 & 9 & 59.0 & 57.8 \\
\hline 13 & 07288595 & 6/14/2006 & 1025 & 514 & 8.0 & 28.0 & 62 & 7.2 & 40 & 173.0 & 48.7 & 0.24 & $<0.10$ & 3.15 & 0.27 & 0.09 & 11 & 57.6 & 29.6 \\
\hline 14 & 07288600 & $5 / 22 / 2006$ & 1430 & 170 & 7.1 & 25.5 & 200 & 7.2 & 25 & 47.7 & 12.6 & 0.52 & 0.15 & 1.97 & 0.41 & 0.11 & 7 & 33.2 & 12.7 \\
\hline 15 & 07288643 & $5 / 23 / 2006$ & 915 & 95 & 7.2 & 23.6 & 82 & 7.1 & 22 & 38.0 & 1.7 & 0.37 & $<0.10$ & 1.10 & 0.25 & 0.15 & 5 & 10.6 & 7.7 \\
\hline 16 & 07288646 & $5 / 23 / 2006$ & 1015 & 135 & 7.1 & 25.4 & 22.5 & 4.9 & 35 & 54.2 & 1.9 & 0.16 & $<0.10$ & 1.32 & 0.21 & 0.11 & 10 & 9.4 & 11.8 \\
\hline 17 & 07288798 & $6 / 20 / 2006$ & 1100 & 354 & 7.2 & 28.6 & 54 & 3.3 & 25 & 154.0 & 13.6 & $<0.02$ & $<0.10$ & 1.70 & 0.17 & 0.04 & 5 & 43.2 & 22.7 \\
\hline 18 & 07288938 & $6 / 21 / 2006$ & 1100 & 339 & 7.3 & 29.0 & 14 & 3.3 & 17 & 132.0 & 15.8 & $<0.02$ & $<0.10$ & 0.96 & 0.1 & 0.05 & 6 & 13.5 & 8.0 \\
\hline 19 & 322908090540900 & $6 / 21 / 2006$ & 1030 & 384 & 7.3 & 29.0 & 17 & 2.2 & 14 & 167.0 & 8.8 & $<0.02$ & $<0.10$ & 0.95 & 0.1 & 0.03 & 6 & 20.2 & 9.7 \\
\hline 20 & 323417090431500 & $5 / 17 / 2006$ & 1100 & 310 & 7.4 & 21.6 & 62 & 5.8 & 19 & 148.0 & 4.4 & 0.19 & $<0.10$ & 1.18 & 0.27 & 0.04 & 6 & 28.2 & 17.4 \\
\hline 21 & 323433090472700 & $6 / 21 / 2006$ & 1200 & 349 & 7.5 & 29.2 & 13 & 4.4 & 15 & 127.0 & 18.3 & $<0.02$ & $<0.10$ & 0.96 & 0.11 & 0.05 & 5 & 17.0 & 10.9 \\
\hline 22 & 324909090421200 & $5 / 18 / 2006$ & 1315 & 78 & 6.3 & 20.0 & 340 & 4.1 & 22 & 28.8 & 2.3 & 0.57 & 0.24 & 0.99 & 0.33 & 0.09 & 5 & 6.0 & 3.4 \\
\hline 23 & 325222090251400 & $5 / 19 / 2006$ & 830 & 105 & 6.9 & 20.3 & 27 & 5.9 & 59 & 48.3 & 2.0 & 0.03 & $<0.10$ & 1.80 & 0.45 & 0.05 & 16 & 71.7 & 20.6 \\
\hline 24 & 325901090465500 & $5 / 18 / 2006$ & 1030 & 86 & 6.2 & 20.6 & 360 & 3.6 & 19 & 23.2 & 2.1 & 0.57 & 0.29 & 0.95 & 0.37 & 0.10 & 4 & 9.6 & 2.8 \\
\hline 25 & 331207090244100 & $5 / 22 / 2006$ & 1030 & 130 & 6.8 & 25.8 & 33 & 6.8 & 47 & 40.6 & 4.4 & $<0.02$ & $<0.10$ & 1.79 & 0.21 & 0.08 & 14 & 29.0 & 18.9 \\
\hline
\end{tabular}


Appendix I. Summary of surface-water analytical results from the U.S. Geological Survey National Water Quality Laboratory and the Mississippi Department of Environmental Quality laboratory for stream sites in northwestern Mississippi, May-June 2006--Continued

\begin{tabular}{|c|c|c|c|c|c|c|c|c|c|c|c|c|c|c|c|c|c|c|c|}
\hline $\begin{array}{c}\text { Site } \\
\text { num- } \\
\text { ber } \\
\text { (fig. } \\
\text { 1) }\end{array}$ & Station number & $\begin{array}{c}\text { Sample } \\
\text { date } \\
\text { (month/ } \\
\text { day/ } \\
\text { year) }\end{array}$ & $\begin{array}{l}\text { Sam- } \\
\text { ple } \\
\text { start } \\
\text { time } \\
(24- \\
\text { hour) }\end{array}$ & $\begin{array}{l}\text { Spe- } \\
\text { cific } \\
\text { con- } \\
\text { duc- } \\
\text { tance, } \\
\text { field } \\
(\mu \mathrm{S} / \\
\mathrm{cm})\end{array}$ & $\begin{array}{l}\mathrm{pH}, \\
\text { field } \\
\text { (stan- } \\
\text { dard } \\
\text { units) }\end{array}$ & $\begin{array}{c}\text { Water } \\
\text { tem- } \\
\text { pera- } \\
\text { ture } \\
\text { (de- } \\
\text { grees } \\
\text { Cel- } \\
\text { sius) }\end{array}$ & $\begin{array}{l}\text { Tubidity } \\
\text { (NTU) }\end{array}$ & $\begin{array}{c}\text { Dissolved } \\
\text { oxygen } \\
\text { (mg/L) }\end{array}$ & $\begin{array}{l}\text { Chemi- } \\
\text { cal } \\
\text { oxygen } \\
\text { demand }\end{array}$ & $\begin{array}{l}\text { Alkalinity } \\
\text { as } \mathrm{CaCO}\end{array}$ & $\begin{array}{l}\text { Chloride } \\
\text { (mg/L as } \\
\text { Cl) }\end{array}$ & $\begin{array}{l}\text { Nitrite plus } \\
\text { nitrate } \\
\text { (mg/ L } \\
\text { as N) }\end{array}$ & $\begin{array}{c}\text { Amonia } \\
(\mathrm{mg} / \mathrm{L} \text { as } \\
\mathrm{N})\end{array}$ & $\begin{array}{c}\text { Nitrogen, } \\
\text { total Kjel- } \\
\text { dahl (mg/L } \\
\text { as N) }\end{array}$ & $\begin{array}{c}\text { Total } \\
\text { phosph- } \\
\text { orus (mg/L } \\
\text { as } \mathrm{P} \text { ) }\end{array}$ & $\begin{array}{l}\text { Dissolved } \\
\text { ortho- } \\
\text { phospho- } \\
\text { rus (mg/L } \\
\text { as P) }\end{array}$ & $\begin{array}{c}\text { Car- } \\
\text { bon, } \\
\text { total } \\
\text { or- } \\
\text { gan- } \\
\text { ic } \\
\text { (mg/ } \\
\text { L) }\end{array}$ & $\begin{array}{c}\text { Chlo- } \\
\text { ro- } \\
\text { phyll- } \\
\text { a } \\
(\mu \mathrm{g} / \mathrm{L})\end{array}$ & $\begin{array}{l}\text { Pheo- } \\
\text { phytin } \\
\text { a, } \\
\text { phyto- } \\
\text { plank- } \\
\text { ton } \\
\text { (mg/L\}) }\end{array}$ \\
\hline 26 & 332844090370800 & $5 / 22 / 2006$ & 1230 & 122 & 7.0 & 22.5 & 220 & 5.4 & 32 & 39.0 & 4.8 & 0.83 & $<0.10$ & 1.79 & 0.37 & 0.10 & 9 & 50.3 & 20.1 \\
\hline 27 & 333328090554800 & $5 / 23 / 2006$ & 1445 & 585 & 7.7 & 29.9 & 48 & 6.6 & 41 & 152.0 & 10.2 & 0.91 & 1.02 & 5.16 & 0.16 & 0.08 & 11 & 14.7 & 8.6 \\
\hline 28 & 333615090061800 & 6/12/2006 & 1225 & 140 & 7.2 & 29.1 & 10 & 7.0 & 15 & 60.9 & 4.9 & 0.13 & $<0.10$ & 0.64 & 0.09 & 0.03 & 8 & 3.0 & 2.6 \\
\hline 29 & 333844090515400 & $5 / 23 / 2006$ & 800 & 96 & 7.8 & 26.3 & 67 & 8.6 & 27 & 41.8 & 1.7 & 0.21 & $<0.10$ & 1.06 & 0.27 & 0.15 & 6 & 17.5 & 15.2 \\
\hline 30 & 334324090262400 & $5 / 25 / 2006$ & 1245 & 570 & 8.1 & 30.4 & 17 & 13.6 & $<10$ & 191.0 & 29.8 & 1.05 & 0.80 & 2.04 & 0.09 & 0.03 & 8 & 8.6 & 4.3 \\
\hline 31 & 334527090350400 & 6/13/2006 & 1500 & 336 & 7.0 & 26.5 & 28 & 4.0 & 39 & 122.0 & 7.3 & $<0.02$ & $<0.10$ & 1.49 & 0.16 & $<0.01$ & 12 & 34.9 & 34.7 \\
\hline 32 & 334747090285000 & $5 / 25 / 2006$ & 1100 & 424 & 7.3 & 24.7 & 89 & 6.1 & 12 & 167.0 & 7.5 & 0.99 & 0.17 & 0.68 & 0.13 & 0.05 & 4 & 2.3 & 1.2 \\
\hline 33 & 335100090225500 & $5 / 24 / 2006$ & 1530 & 103 & 7.0 & 31.6 & 100 & 6.6 & 37 & 43.4 & 2.0 & 0.15 & $<0.10$ & 1.37 & 0.34 & 0.10 & 10 & 19.9 & 9.6 \\
\hline 34 & 335100090225700 & $5 / 24 / 2006$ & 1345 & 188 & 7.5 & 30.2 & 150 & 8.4 & 46 & 81.3 & 4.4 & $<0.02$ & $<0.10$ & 1.92 & 0.38 & 0.04 & 11 & 61.5 & 30.8 \\
\hline 35 & 335105090415300 & $5 / 24 / 2006$ & 745 & 435 & 7.6 & 25.4 & 84 & 3.9 & 55 & 195.0 & 15.6 & $<0.02$ & $<0.10$ & 3.3 & 1.43 & 1.07 & 9 & 67.7 & 64.8 \\
\hline 36 & 335458090287000 & $5 / 25 / 2006$ & 945 & 131 & 6.8 & 26.8 & 73 & 1.6 & 56 & 61.0 & 2.0 & $<0.02$ & $<0.10$ & 1.84 & 0.74 & 0.11 & 14 & 43.4 & 39.8 \\
\hline 37 & 335604090075800 & 6/13/2006 & 900 & 264 & 6.7 & 23.6 & 25 & 4.7 & 19 & 113.0 & 13.7 & 0.09 & $<0.10$ & 0.73 & 0.15 & 0.06 & 4 & 1.6 & 2.7 \\
\hline 38 & 335737090270100 & $5 / 24 / 2006$ & 1200 & 120 & 8.4 & 29.0 & 56 & 11.8 & 48 & 58.8 & 1.6 & $<0.02$ & $<0.10$ & 1.71 & 0.75 & 0.12 & 12 & 91.3 & 43.0 \\
\hline 39 & 335749090273300 & $5 / 24 / 2006$ & 1100 & 115 & 6.9 & 26.4 & 50 & 3.2 & 29 & 48.0 & 1.9 & 0.07 & 0.64 & 1.7 & 0.77 & 0.28 & 8 & 3.3 & 2.1 \\
\hline 40 & 340030090155300 & 6/13/2006 & 955 & 365 & 7.6 & 25.7 & 30 & 5.0 & $<10$ & 168.0 & 13.2 & 0.06 & $<0.10$ & 1.31 & 0.3 & 0.15 & 9 & 9.0 & 10.4 \\
\hline 41 & 340157090071200 & $6 / 13 / 2006$ & 1115 & 282 & 7.1 & 24.7 & 81 & 2.3 & 39 & 130.0 & 12.3 & 0.05 & 0.16 & 2.26 & 0.35 & 0.03 & 12 & 26.0 & 22.3 \\
\hline 42 & 340423090210800 & $5 / 25 / 2006$ & 830 & 150 & 6.7 & 25.3 & 180 & 3.9 & 29 & 66.7 & 4.2 & 0.27 & 0.65 & 2.13 & 0.83 & 0.20 & 8 & 35.1 & 22.4 \\
\hline 43 & 340507090345400 & 6/13/2006 & 1700 & 497 & 8.0 & 28.4 & 56 & 8.4 & 21 & 212.0 & 20.3 & 0.49 & 0.22 & 1.02 & 0.13 & 0.08 & 8 & 1.6 & 2.3 \\
\hline 44 & 341341090413100 & 6/12/2006 & 1200 & 305 & 7.3 & 29.7 & 21 & 5.6 & 28 & 137.0 & 9.6 & 0.03 & $<0.10$ & 1.44 & 0.22 & 0.10 & 14 & 5.6 & 5.6 \\
\hline 45 & 341508090302500 & $6 / 12 / 2006$ & 1545 & 265 & 8.5 & 30.5 & 49 & 7.6 & 50 & 113.0 & 14.2 & $<0.02$ & $<0.10$ & 2.37 & 0.46 & 0.15 & 20 & 4.0 & 9.1 \\
\hline 46 & 341556090243100 & 6/13/2006 & 800 & 860 & 7.4 & 21.2 & 86 & 2.6 & 21 & 210.0 & 134.0 & 0.05 & $<0.10$ & 0.91 & 0.49 & 0.37 & 4 & 9.9 & 21.8 \\
\hline 47 & 341701090113300 & $5 / 31 / 2006$ & 1245 & 307 & 7.6 & 28.4 & 35 & 11.1 & 42 & 120.0 & 8.8 & 0.17 & 1.11 & 3.77 & 0.17 & 0.02 & 10 & 88.3 & 46.4 \\
\hline 48 & 342328090273700 & $6 / 12 / 2006$ & 1430 & 163 & 7.6 & 30.7 & 29 & 5.7 & 13 & 73.2 & 4.5 & 0.06 & 0.14 & 1.46 & 0.16 & 0.05 & 6 & 11.8 & 8.7 \\
\hline 49 & 343553090165700 & $5 / 30 / 2006$ & 1200 & 333 & 7.2 & 26.6 & 18 & 3.9 & 43 & 146.0 & 10.7 & 0.75 & 0.46 & 2.02 & 0.12 & 0.06 & 12 & 7.2 & 7.7 \\
\hline 50 & 344246090263600 & $5 / 30 / 2006$ & 1605 & 207 & 7.3 & 30.3 & 33 & 3.3 & 75 & 100.0 & 2.3 & $<0.02$ & $<0.10$ & 2.27 & 0.65 & 0.11 & 19 & 27.1 & 22.8 \\
\hline 51 & 344251090233100 & $5 / 30 / 2006$ & 1445 & 160 & 7.0 & 31.0 & 77 & 4.6 & 41 & 76.5 & 1.3 & 0.03 & 0.31 & 1.84 & 0.3 & 0.05 & 9 & 46.0 & 39.1 \\
\hline 52 & 344516090164400 & $5 / 30 / 2006$ & 1030 & 242 & 6.9 & 25.2 & 180 & 5.7 & 39 & 106.0 & 7.7 & $<0.02$ & 0.10 & 2.18 & 0.48 & 0.07 & 12 & 116.0 & 36.2 \\
\hline
\end{tabular}


Appendix 2. Quality assurance data from the U.S. Geological Survey National Water Quality Laboratory and the Mississippi Department of Envioronmental Quality laboratory for water-quality samples from stream sites in northwestern Mississippi, May-June 2006

[TKN, total Kjeldahl nitrogen; CaCO3; calcium carbonate; mg/L, milligrams per liter; ug/L, micrograms per liter; <, less than]

\begin{tabular}{|c|c|c|c|c|c|c|c|c|c|c|c|c|c|c|}
\hline $\begin{array}{l}\text { Site } \\
\text { number } \\
\text { (fig. } \\
\text { 1) }\end{array}$ & Station number & $\begin{array}{c}\text { Date } \\
\text { (month/ } \\
\text { day/year) }\end{array}$ & $\begin{array}{c}\text { Sample } \\
\text { start } \\
\text { time } \\
\text { (24- } \\
\text { hour) }\end{array}$ & $\begin{array}{l}\text { Chemical } \\
\text { oxygen } \\
\text { demand } \\
\text { (mg/L) }\end{array}$ & $\begin{array}{l}\text { Alkalinity } \\
\text { as } \mathrm{CaCO3}\end{array}$ & $\begin{array}{l}\text { Chloride } \\
\text { (mg/L as } \\
\text { CI) }\end{array}$ & $\begin{array}{l}\text { Nitrite } \\
\text { plus ni- } \\
\text { trate (mg/ } \\
\text { L as N) }\end{array}$ & $\begin{array}{c}\text { Ammonia } \\
\text { (mg/L as } \\
\mathrm{N})\end{array}$ & $\begin{array}{c}\text { Nitrogen, } \\
\text { total } \\
\text { Kjeldahl } \\
\text { (mg/L as } \\
\mathrm{N} \text { ) }\end{array}$ & $\begin{array}{c}\text { Total } \\
\text { phosph- } \\
\text { orus } \\
\text { (mg/L as } \\
\text { P) }\end{array}$ & $\begin{array}{c}\text { Dissolved } \\
\text { ortho- } \\
\text { phospho- } \\
\text { rus (mg/L } \\
\text { as P) }\end{array}$ & $\begin{array}{c}\text { Carbon, } \\
\text { total } \\
\text { organic } \\
\text { (mg/L) }\end{array}$ & $\begin{array}{l}\text { Chloro- } \\
\text { phyll-a } \\
\text { ( } \mu \mathrm{g} / \mathrm{L})\end{array}$ & $\begin{array}{c}\text { Pheo- } \\
\text { phytin a, } \\
\text { phyto- } \\
\text { plankton } \\
\text { (ug/L) }\end{array}$ \\
\hline 5 & 7280555 & $6 / 13 / 2006$ & 1245 & 10 & 50.5 & 7.2 & 0.05 & $<0.10$ & 0.44 & 0.09 & 0.03 & 8 & 5.8 & 6.5 \\
\hline 5 & 7280555 & $6 / 13 / 2006$ & 1300 & 12 & 49.5 & 6.6 & 0.05 & $<0.10$ & 0.53 & 0.10 & 0.03 & 4 & 5.3 & 6.0 \\
\hline 8 & 7286006 & $6 / 12 / 2006$ & 1630 & 79 & 141.0 & 6.4 & $<0.02$ & $<0.10$ & 0.31 & 0.06 & 0.05 & 11 & 1.1 & 1.3 \\
\hline 8 & 7286006 & $6 / 12 / 2006$ & 1650 & $<10$ & 145.0 & 6.7 & $<0.02$ & $<0.10$ & 0.45 & 0.05 & 0.04 & 12 & 1.3 & 1.2 \\
\hline 21 & 323433090472700 & $6 / 21 / 2006$ & 1200 & 15 & 127.0 & 18.3 & $<0.02$ & $<0.10$ & 0.96 & 0.11 & 0.05 & 5 & 17.0 & 10.9 \\
\hline 21 & 323433090472700 & $6 / 21 / 2006$ & 1201 & 14 & 125.0 & 18.2 & $<0.02$ & $<0.10$ & 0.94 & 0.11 & 0.05 & 6 & 16.6 & 10.9 \\
\hline 23 & 325222090251400 & $5 / 19 / 2006$ & 830 & 59 & 48.3 & 2.0 & 0.03 & $<0.10$ & 1.80 & 0.45 & 0.05 & 16 & 71.7 & 20.6 \\
\hline 23 & 325222090251400 & $5 / 19 / 2006$ & 845 & 59 & 48.5 & 1.8 & $<0.02$ & $<0.10$ & 2.20 & 0.44 & 0.06 & 16 & 74.2 & 21.2 \\
\hline 27 & 333328090554800 & $5 / 23 / 2006$ & 1445 & 41 & 152.0 & 10.2 & 0.91 & 1.02 & 5.16 & 0.16 & 0.08 & 11 & 14.7 & 8.6 \\
\hline 27 & 333328090554800 & $5 / 23 / 2006$ & 1450 & 37 & 153.0 & 9.8 & 0.92 & 0.99 & 5.17 & 0.18 & 0.09 & 11 & 15.9 & 8.9 \\
\hline 51 & 344251090233100 & $5 / 30 / 2006$ & 1445 & 41 & 76.5 & 1.3 & 0.03 & 0.31 & 1.84 & 0.30 & 0.05 & 9 & 46.0 & 39.1 \\
\hline 51 & 344251090233100 & $5 / 30 / 2006$ & 1500 & 40 & 78.5 & 1.6 & 0.03 & 0.31 & 1.41 & 0.30 & 0.05 & 9 & 46.9 & 40.9 \\
\hline
\end{tabular}




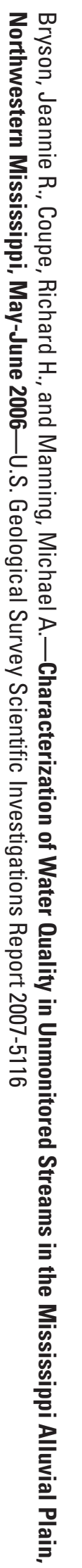

8 Printed on recycled paper 